\title{
Association of age, sex, comorbidities, and clinical symptoms with the severity and mortality of COVID-19 cases: a meta-analysis with 85 studies and 67299 \\ cases
}

Mohammad Safiqul Islam ${ }^{1}$, Md. Abdul Barek ${ }^{1}$, Md. Abdul Aziz ${ }^{1}$, Tutun Das Aka ${ }^{1}$, Md. Jakaria²

${ }^{1}$ Department of Pharmacy, Noakhali Science and Technology University, Noakhali-3814, Bangladesh

${ }^{2}$ The Florey Institute of Neuroscience and Mental Health, The University of Melbourne, Parkville, VIC 3010, Australia

* Correspondence: research_safiq@yahoo.com

\section{Abstract}

Background: A new pathogenic disease named COVID-19 became a global threat, first reported in Wuhan, China, in December 2019. The number of affected cases growing exponentially and now, more than 210 countries confirmed the cases.

Objective: This meta-analysis aims to evaluate risk factors, the prevalence of comorbidity, and clinical characteristics in COVID-19 death patients compared to survival patients that can be used as a reference for further research and clinical decisions.

Methods: PubMed, Science Direct, SAGE were searched to collect data about demographic, clinical characteristics, and comorbidities of confirmed COVID-19 patients from January 1, 2020, to May 17, 2020. Meta-analysis was performed with the use of Review Manager 5.3

Results: Eighty-five studies were included in Meta-analysis, including a total number of 67,299 patients with SARS-CoV-2 infection. Males are severely affected or died than females $(\mathrm{OR}=2.26, \mathrm{p}$ $<0.00001 ; \mathrm{OR}=3.59, \mathrm{p}<0.00001)$ are severely affected, or died by COVID-19 and cases with age $\geq 50$ are at higher risk of death than age $<50$ years $(\mathrm{OR}=334.23)$. Presence of any comorbidity or comorbidities like hypertension, cardiovascular disease, diabetes, cerebrovascular disease, respiratory disease, kidney disease, liver disease, malignancy significantly increased the risk of death compared to survival $(\mathrm{OR}=3.46,3.16,4.67,2.45,5.84,2.68,5.62,2.81,2.16)$. Among the clinical characteristics such as fever, cough, myalgia, diarrhea, abdominal pain, dyspnea, fatigue, sputum production, chest tightness headache and nausea or vomiting, only fatigue (OR $=1.31,95 \%)$ and dyspnea increased the death significantly $(\mathrm{OR}=1.31,4.57)$. The rate of death of COVID-19 cases is 0.03 -times lower than the rate of survival $(\mathrm{OR}=0.03)$.

\section{Conclusion}

Our result indicates that male patients are affected severely or died, the rate of death is more in the age $\geq 50$ group, and the rate of death is affected by comorbidities and clinical symptoms. 
medRxiv preprint doi: https://doi.org/10.1101/2020.05.23.20110965; this version posted May 26, 2020. The copyright holder for this preprint (which was not certified by peer review) is the author/funder, who has granted medRxiv a license to display the preprint in perpetuity.

It is made available under a CC-BY-ND 4.0 International license.

Keywords: COVID-19; Pneumonia; Meta-analysis; Survival; Mortality; Risk factor; Comorbidity; Clinical manifestation 
medRxiv preprint doi: https://doi.org/10.1101/2020.05.23.20110965; this version posted May 26, 2020. The copyright holder for this preprint

\section{Introduction}

A cluster of critical cases with pneumonia arising from a new unknown pathogenic virus was first reported in Wuhan, Hubei, China, on December 31, 2019 [1]. Only a few days later, researchers have identified the virus which belongs to a relatively well-known viral family, Coronaviridae, and is similar to Bat SARS-like coronavirus (with $88 \%$ identity) and have identical nucleotide with the original SARS (80\%), and MERS-Cov (about 50\%) epidemic virus [2]. Based on phylogeny, taxonomy, and established practice, the International Committee on Taxonomy of Viruses named this pathogen as severe acute respiratory syndrome coronavirus-2 (SARS-CoV-2) [3]. Within a short time, novel coronavirus-infected pneumonia (NCIP) spread rapidly to the whole world. World Health Organization (WHO) declared NCIP as a Public and Global Health Emergency of Concern on January 30,2020 , and officially renamed this pandemic disease is coronavirus disease 2019 (COVID-19) on February 11, 2020 [3]. More than 210 countries already confirmed this case, and the case number is climbing rapidly day by day in the world reported by the WHO. As of May 17, 2020, about 4720196 cases with laboratory-confirmed COVID-19 infection have been detected, and 313220 (15\%) died worldwide [4].

In China, the case number is gradually decreasing but rapidly increasing in other countries, especially in the USA, Italy, South Korea, and Iran. Coronavirus spike (S) glycoproteins bind with angiotensinconverting enzyme 2 (ACE2) receptors to promote entry into cells [5]. This new coronavirus is mainly transmitted through respiratory droplets and also can be transmitted by asymptomatic carriers. Several research studies report that this virus incubates 1 to 14 days in the human body [6]. It is essential to find out the clinical characteristics in the early stage to detect and isolate patients earlier and to minimize its transmission. Several clinical studies demonstrated that maximum confirmed patients had various symptoms (fever, cough, headache, dyspnea, myalgia, diarrhea, fatigue, nausea, and vomiting, etc.) with single or multiple comorbidities including cardiovascular disease, diabetes, hypertension, liver disease, kidney disease, and chronic obstructive pulmonary disease but asymptomatic individuals have also been identified as potential sources of infection [7]. The patients admitted to the intensive care unit (ICU) had a higher number of comorbidities than those not admitted to the ICU. SARS-CoV-2 can be transmitted through respiratory tract infections and develop severe pneumonia in infected patients like other viral respiratory infections. Severe patients may require intensive care and sometimes may result in death due to progressive respiratory failure. Everyone is susceptible to this virus, but the elderly and those with underlying diseases are more prone to adverse outcomes [8]. There are no approved drugs or vaccines in the world for fighting against COVID-19 [9]. Researchers are trying to develop medicine and vaccine to combat COVID-19 and upcoming SARS and MERS viruses [9]. There is an urgent need to find alternative ways of controlling the 
medRxiv preprint doi: https://doi.org/10.1101/2020.05.23.20110965; this version posted May 26, 2020. The copyright holder for this preprint

(which was not certified by peer review) is the author/funder, who has granted medRxiv a license to display the preprint in perpetuity.

It is made available under a CC-BY-ND 4.0 International license .

spread of this disease. Many researchers published clinical research on COVID-19, but the reported results were not all the same. However, for more accurate conclusions and further clinical practice, we collected the relevant studies about the clinical characteristics of COVID-19 to carry out an updated meta-analysis to describe epidemiological features, clinical characteristics, the prevalence of comorbidities, assess the risk of underlying diseases, and outcomes of death, as well as the survival of patients, confirmed to have the 2019-nCoV infection. Our findings may provide vital guidance for current clinical work on the prevention, treatment, and control of the current outbreak.

\section{Methods}

\subsection{Search databases and search strategies}

This meta-analysis was conducted by following the guidelines of PRISMA. The relevant studies were systematically searched in PubMed, ScienceDirect, and SAGE database from January 1, 2020, to May 17, 2020. EndNote X 7.0 software records are used to exclude duplicates. The following keywords are used in search alone or in combination: clinical characteristics of COVID-19, clinical outcome, death or clinical features, comorbidities of COVID-19, signs and symptoms of SARS-CoV2. To identify the studies, there has no language or country limitation, and the search was restricted to humans, but only literature published online was included. We also checked reference lists of included studies to identify missing studies.

\subsection{Study eligibility}

\subsubsection{Inclusion criteria}

1) Cohort studies and case series studies; 2) Study population confirmed with COVID-19; 3) The primary outcomes were: age, sex, clinical symptoms, signs, comorbidities, mortality; 4) No language and country restriction.

\subsubsection{Exclusion criteria}

1) Reviews, editorials, letters, and commentaries; 2) Children and pregnant women case;

3) Overlapping or duplicate publications; 4) Irrelevant information for data extraction.

\subsection{Data extraction and quality assessment}

Rayyan QCRI, a systematic review web app, was used for the selection of the studies [10]. Literature search, evaluation, and data extraction to an excel database were conducted independently by two investigators (MAB and MAA) with the inclusion criteria. TDA and MSI resolved disagreements. Data extraction includes author, country, age, gender, number of participates, clinical symptoms, 
medRxiv preprint doi: https://doi.org/10.1101/2020.05.23.20110965; this version posted May 26, 2020. The copyright holder for this preprint

(which was not certified by peer review) is the author/funder, who has granted medRxiv a license to display the preprint in perpetuity.

It is made available under a CC-BY-ND 4.0 International license .

comorbidities, severity, death number, death patient's age, gender, death number with comorbidities. Newcastle Ottawa Scale (NOS) Guidelines were followed for observational cohort studies to determine the quality of the included studies, as described elsewhere [11]. Jadad scale was used for randomized controlled trials ( RCTs) to determine the consistency of the sample [12].

\subsection{Statistical analysis}

All analyses were performed by Microsoft Excel and Review Manager 5.3 (RevMan 5.3, The Cochrane Collaboration, Oxford, United Kingdom). Heterogeneity $\left(\chi^{2}\right.$ and $\left.\mathrm{I}^{2}\right)$ between studies calculated using Review Manager 5.3. Heterogeneity in the forest plot was evaluated using both the Cochrane chi-square $Q$-test and $\mathrm{I}^{2}$ statistic. There was statistically significant heterogeneity if $p<0.1$ or $\mathrm{I}^{2}>50 \%$. $\mathrm{I}^{2}$ values of $25 \%, 50 \%$, and $75 \%$ represented low, moderate, and high heterogeneity, respectively. Sensitivity analysis was performed to quantify any significant variations in risk between the studies for each parameter by omitting studies one by one. Based on heterogeneity, the fixed effect model was used if $\mathrm{I}^{2} \leq 50 \%$, and the random effect model was used if $\mathrm{I}^{2}>50 \%$. Publication bias was evaluated by funnel plot along with Egger's regression test. The level of significance of publication bias was $\mathrm{p}<0.05$, the values larger than which were considered as no publication bias.

\section{Results}

\subsection{Literature retrieval and Quality Assessment}

Based on the initial search strategy, 2328 citations were found in different databases. A total of 539 records were retained after deleting duplicate records. Three hundred six articles were excluded after reviewing the title and abstract and 46 of the remaining 233 articles were excluded for various reasons. After a detailed assessment based on the inclusion criteria, finally, 85 articles [13-97] were included in the meta-analysis published in 2020, comprising of 67299 confirmed cases (Table 1). Fig. 1 described the whole process of the selection of studies. It was also found that most of these studies $(n=69)$ were based in China, although eight studies and six studies were identified from the USA and Italy, respectively. One study from South Korea and one study from Iran were also included. The quality of most included studies, assessed by the Newcastle Ottawa scale, was of high quality (score ranges between 6-8), with only two studies being of moderate quality (score 5), as shown in Table 2.

\subsection{Effect of sex on disease severity}

Fifty-five studies reported the sex wise disease severity, and significant heterogeneity was found when the severity of the male and female COVID-19 patients were compared $\left(\mathrm{I}^{2}=79 \%, \mathrm{p}<0.00001\right)$. 
medRxiv preprint doi: https://doi.org/10.1101/2020.05.23.20110965; this version posted May 26, 2020. The copyright holder for this preprint

(which was not certified by peer review) is the author/funder, who has granted medRxiv a license to display the preprint in perpetuity.

It is made available under a CC-BY-ND 4.0 International license.

The random-effect model was used in the meta-analysis and the proportion of severe patients in the male group was significantly higher than the female group, and male patients showed 2.26-times more risk of death than female patients (male vs. female; 57.74 vs. $42.36 \%$, OR $=2.26 ; 95 \% \mathrm{CI}=$ 1.79-2.86; $<<0.00001)$ (Fig. 2).

\subsection{Effect of sex on death}

A total of thirty-four studies described the sex wise death report. Male patients with COVID-19 shown 3.59-times more risk of death compared to female patients (male vs. female; 65.45 vs. 34.45\%, $\mathrm{OR}=3.59 ; 95 \% \mathrm{CI}=2.80-4.62, \mathrm{p}<0.00001)$. Significant heterogeneity was also reported in this finding $\left(\mathrm{I}^{2}=56 \%, \mathrm{p}<0.0001\right)$. (Fig. 2).

\subsection{Effect of age on the death}

Among the 85 studies, 41 studies reported death according to the age range, and only 152 deaths in females were found within a total of 3405 deaths. A higher significant heterogeneity also found in this case $\left(\mathrm{I}^{2}=87 \%, \mathrm{p}<0.0001\right)$. Covid-19 patients age more than 50 years showed 334.23 times more risk of death in comparison with COVID-19 patients aged below 50 years (age $\geq 50$ years vs. age $<50$ years: 95.54 vs. $4.46 \%, \mathrm{OR}=324.23 ; 95 \% \mathrm{CI}=139.25-802.20$, $\mathrm{p}<0.00001$ ). (Fig. 3)

\subsection{Comorbidity}

The prevalence of comorbidities including hypertension, diabetes, respiratory disease, cardiovascular diseases, cerebrovascular disease, renal disease, liver disease, malignancy, and gastrointestinal (GI) disease in death and survived patients of the included studies is shown in Fig. 4. Among the different comorbidities, $68.25 \%$ of patient death was due to the presence of at least one comorbidity, and patients having at least one comorbidity had 3.46-times risk of death than survived patients $(\mathrm{OR}=$ $3.46,95 \% \mathrm{CI}=2.56-4.67, \mathrm{p}<0.00001)$.

A total of $31 \%$ death was found due to hypertension in comparison to the survival $(6.77 \%)$ with hypertension, and the chance of death was found 3.16-times higher in comparison to survival patients with hypertension $(\mathrm{OR}=3.16,95 \% \mathrm{CI}=2.51-3.97, \mathrm{p}<0.00001)$. The proportion of death in cerebrovascular disease and cardiovascular disease was also higher than the survival rate with these diseases $(12.92 \%$ vs. $14.78 \%$ death, $\mathrm{OR}=5.84,95 \% \mathrm{CI}=3.63-9.39), \mathrm{p}<0.00001 ; \mathrm{OR}=4.67,95 \%$

$\mathrm{CI}=3.22-6.77, \mathrm{p}<0.00001$, respectively). The percentages of death with diabetes, respiratory disease, kidney disease, and liver diseases were significantly higher than the survival rates with these diseases (death vs. survival: 15.63 vs. $2.66 \%$; 6.92 vs. $1.25 \%$; 7.69 vs. $2.32 \% ; 3.74$ vs. $1.43 \%$, 
medRxiv preprint doi: https://doi.org/10.1101/2020.05.23.20110965; this version posted May 26, 2020. The copyright holder for this preprint

respectively). Covid-19 patients with diabetes, respiratory disease, kidney disease, and liver diseases had significantly $2.45,2.68,5.62$ and 2.81-times more risk of death, respectively, compared to survival with these diseases.

The percentage of survival of COVID-19 patients with malignancy is very low (0.44\%) and COVID19 patients with malignancy had 2.16-times more risk of death compared to survival $(\mathrm{OR}=2.16,95 \%$ $\mathrm{Cl}=1.41-3.33, \mathrm{p}=0.0004)$.

No association was found with the death of COVID-19 patients having GI disease as comorbidity ( $p>0.05)$. Overall, the Covid-19 patients with comorbidity had 3.29-times more significant risk of death than survival $(\mathrm{OR}=3.29,95 \% \mathrm{Cl}=2.89-3.76, \mathrm{p}<0.00001)$.

\subsection{Clinical Manifestation}

Fourteen studies reported each of fever and cough, 12 studies reported fatigue, 11 studies reported each of dyspnea and diarrhea, 8 studies reported each of myalgia and headache, 6 studies reported nausea or vomiting, 5 studies reported each of sputum production and chest tightness and 4 studies reported abdominal pain. The most prevalent clinical symptoms were fever $(91.68 \%)$ and cough (74.4\%) followed by dyspnea (47.71\%), fatigue (45.94\%), sputum production $(37.56 \%)$, chest tightness $(36.90 \%)$, myalgia $(23.73 \%)$, diarrhea $(22.44 \%)$, headache $(14.73 \%)$, nausea or vomiting (13.28\%), and abdominal pain (12.29\%). Among the different clinical symptoms, fatigue (OR = 1.31, $95 \% \mathrm{Cl}=1.04-1.66, \mathrm{p}=0.02)$ and dyspnea increased the death significantly $(\mathrm{OR}=4.57,95 \% \mathrm{Cl}=$ 2.69-7.78, $\mathrm{p}<0.0001)$. The chest tightness remained in the borderline $(\mathrm{OR}=2.04,95 \% \mathrm{Cl}=0.99$ $4.20, \mathrm{p}=0.05)$, whereas no association of death was found with the other clinical symptoms (Fig. 5). The overall impact of clinical symptoms on death is also high $(\mathrm{OR}=1.25,95 \% \mathrm{Cl}=1.06-1.48, \mathrm{p}=$ $0.007)$ with a significant heterogeneity $(\mathrm{p}<0.00001)$.

\subsection{Mortality}

The rate of mortality is significantly lower than the rate of survival (death vs. servival: $6.42 \%$ vs. 93.48\%) and the rate of death is 0.03 -times lower than the rate of survival $(\mathrm{OR}=0.03,95 \% \mathrm{CI}=$ 0.01-0.06, $\mathrm{p}<0.00001)$ with a significant higher heterogeneity $\left(\mathrm{I}^{2}=99 \%, \mathrm{p}<0.00001\right)$ (Fig. 6).

\subsection{Sensitivity and Publication bias}

A sensitivity test was carried out by omitting the studies one by one in case of all the study parameters to assess the stability of the pooled result. No mentionable significant deviation was found in the case of all studied parameters. Fig. 7 depicts the impact of sex on disease severity, and the odds ratio was 
medRxiv preprint doi: https://doi.org/10.1101/2020.05.23.20110965; this version posted May 26, 2020. The copyright holder for this preprint

not deviated significantly after omitting each study individually. Eagger's test was performed to evaluate the regression asymmetry and indicated there was no notable evidence of publication bias.

Fig. 8 showed the funnel plot of malignancy as one of the comorbidity parameters.

\section{Discussion}

COVID-19 is the third contagious coronavirus disease after severe acute respiratory syndrome (SARS) and the Middle East respiratory syndrome (MERS) [98]. The outbreak of COVID-19 has been declared a Public Health Emergency of International Concern by WHO. By May 17, 2020, the epidemic had spread to more than 210 countries and with the rising incidence of COVID-19 all over the world. As a newly emerging infectious disease, it is essential to identify the key clinical characteristics of COVID-19 patients to help in early detection and isolation of infected individuals, as well as minimize the spread of the disease, severity, and death rate. So, we completed a systemic meta-analysis that included 85 studies from December 2019 to May 17, 2019, to analyze prevalence and impact of age, sex, severity, comorbidity, clinical symptoms, and different outcomes with COVID-19. Our study included 5 countries, included 67,299 patients, and reflects the most recent data since the emergence of novel coronaviruses.

In our study, we have found that male patients are severely affected $(\mathrm{OR}=2.26, \mathrm{p}<0.00001)$ or died $(\mathrm{OR}=3.59, \mathrm{p}<0.00001)$ by COVID-19 rather than female and age over 50 years $(\geq 50$ years age vs. age $<50: \mathrm{OR}=334.23,95 \% \mathrm{CI}=139.25-802.20, \mathrm{p}<0.00001)$ has a significantly higher risk of death. Female death or severities are lower, possibly due to the presence and protection of sex hormones and $X$ chromosome, which play an important role in innate and adaptive immunity [99]. On the other hand, men associated with a healthy lifestyle. Several studies found that males are more likely to be infected than females during MERS-CoV and SARS-CoV pandemic [100,101]. Elderly people, severe and higher frequency of comorbidities patients are more susceptible to SARS-CoV-2 [102]. In our meta-analysis, we have found that patients having comorbidities are more prone to disease progression and death by COVID-19 comorbidities: (for at least one comorbidity carriers: death vs. survival: $\mathrm{OR}=3.46,95 \% \mathrm{CI}=2.56-4.67, \mathrm{p}<0.00001)$. We also found that, hypertension $(\mathrm{OR}=3.16$, $\mathrm{p}<0.00001)$, cardiovascular diseases (OR=4.67, $\mathrm{p}<0.00001)$, diabetes (OR- 2.45, $\mathrm{p}<0.00001)$, cerebrovascular disease $(\mathrm{OR}=5.84, \mathrm{p}<0.00001)$, respiratory disease $(\mathrm{OR}=2.68, \mathrm{p}<0.00001)$, liver disease $(\mathrm{OR}=2.81, \mathrm{p}=0.008)$, kidney disease $(\mathrm{OR}=5.62, \mathrm{p}<0.00001)$, malignancy $(\mathrm{OR}=2.16, \mathrm{p}=$ 0.0004) were most prevalent between death groups compared to the survival group and increased the rate of death significantly compared to survival, whereas and GI disorder was not associated with the COVID related death $(\mathrm{OR}=1.43, \mathrm{p}=0.49)$. After performing the overall analysis of all 
medRxiv preprint doi: https://doi.org/10.1101/2020.05.23.20110965; this version posted May 26, 2020. The copyright holder for this preprint

comorbidities, we found that comorbidities increased the death 3.29 times compared to overall survival $(\mathrm{OR}=3.29, \mathrm{p}<0.00001)$. Comorbidities and their susceptibility conditions may decrease immunity, impair macrophage and lymphocyte function, and linked to the pathogenesis of COVID19 [103]. Heart disease patients with SARS-CoV-2 may develop a severe condition. Diabetes increases metabolic disorder and induces inflammatory infection [104]. Respiratory disorders like chronic obstructive pulmonary disease patients have lower resistance to the virus and are prone to developing ARDS and this is consistent with our findings. Hypertension and diabetes mellitus are consistent with the prevalence in China that were $21.1 \%$ and $9.7 \%$ in COVID-19 patients, respectively [103].

Furthermore, a study analyzed that diabetes, smoking, and heart disease were also significantly associated with MERS-CoV illness [105]. In this meta-analysis, we also observed that clinical manifestations- fever cough, myalgia, diarrhea, and abdominal pain were common both in death and survival patients but had significant clinical characteristics difference in fatigue $(O R=1.31, p=0.02)$, dyspnea $(\mathrm{OR}=4.57, \mathrm{p}<0.00001)$, and chest tightness $(\mathrm{OR}=2.04, \mathrm{p}=0.05)$ in both groups. Fatigue and dyspnea associated significantly with an increased risk of death compared to survival. Sputum production, headache, and nausea/vomiting were higher in the death group compared with the survival group. Several clinical researchers found that the common clinical manifestations of COVID19 patients are fever, cough, headache, fatigue, myalgia, nausea, diarrhea, and sputum and others $[106,107]$ that are also common in our studies. The rate of mortality found in this study also significantly lower than the survival (death vs. survival: $6.42 \%$ vs. $93.48 \%$, OR $=0.03,95 \% \mathrm{CI}=$ $0.01-0.06, \mathrm{p}<0.00001)$.

Previously, two coronavirus outbreak occurred, which are associated with the more critical disease: the SARS coronavirus in 2002-2003 and the Middle East respiratory syndrome coronavirus that have almost similar characteristics of patients with COVID-19, but there have no studies on the relation of severity and mortality with comorbidity. Similarly, there is no meta-analysis published on the severity of gender and mortality with gender, age, comorbidity, and symptoms for COVID-19 infected patients. Therefore, this is a novel systematic review and meta-analysis. Due to the lack of evidence, we present this meta-analysis by consolidating multiple retrospective studies that help to make proper and effective decisions in the future about COVID-19 patients to decrease the severity and mortality rate. It is by far the first meta-analysis with a larger sample size, and the quality of the literature included in this study is intense; the analysis is rigorous, and the conclusions drawn by the study are highly credible. However, some limitations should be mentioned. Firstly, most of the studies included in this meta-analysis were not RCTs. Secondly, high heterogeneity statistics could be found due to the larger variations in sample size. Thirdly, reports being restricted to China and a few other countries 
and our aim to use this study's results to forecast patients in general, including other countries and races. Fourthly, severity, morbidity, and follow-up of patients in different hospitals vary greatly. Without these limitations, this study analyzed the risk factors for progression to critical illness or death in COVID-19 patients to help to assess patient status and identify critical patients early. Paying close attention to these risk factors and personalized treatment regimens are needed to enhance the efficacy as well as reduce the risk of death.

\section{Conclusion}

COVID-19 pandemic has led to a major health concern globally. Our results note that males and the age of more than 50 years in both sexes are at higher risk of COVID-19 infection severity and death. Most of the comorbidities, such as hypertension, diabetes, respiratory disease, cardiovascular diseases, cerebrovascular disease, renal disease, liver disease, malignancy, are responsible for increasing the COVID-19 related death. The most common symptoms of COVID-19 death and survival patients were fever, cough, fatigue, dyspnea, myalgia, diarrhea and headache, whereas fatigue and dyspnea are associated with increased death. This meta-analysis will help to make proper decisions to identify risk factors and critical patients to give suitable treatment and management promptly.

\section{Conflict of interest}

The authors announce that they do not have a conflict of interest. 
medRxiv preprint doi: https://doi.org/10.1101/2020.05.23.20110965; this version posted May 26, 2020. The copyright holder for this preprint

(which was not certified by peer review) is the author/funder, who has granted medRxiv a license to display the preprint in perpetuity.

It is made available under a CC-BY-ND 4.0 International license.

\section{Reference}

1. Chan JF, Yuan S, Kok KH, To KK, Chu H, Yang J, Xing F, Liu J, Yip CC, Poon RW et al: A familial cluster of pneumonia associated with the 2019 novel coronavirus indicating person-to-person transmission: a study of a family cluster. Lancet 2020, 395(10223):514523.

2. Zheng J: SARS-CoV-2: an Emerging Coronavirus that Causes a Global Threat. International journal of biological sciences 2020, 16(10):1678-1685.

3. Lai CC, Shih TP, Ko WC, Tang HJ, Hsueh PR: Severe acute respiratory syndrome coronavirus 2 (SARS-CoV-2) and coronavirus disease-2019 (COVID-19): The epidemic and the challenges. International journal of antimicrobial agents 2020, 55(3):105924.

4. Worldometers.info: Confirmed cases and deaths by country, territory, or conveyance. In. Dover, Delaware, U.S.A; 2020.

5. Walls AC, Park YJ, Tortorici MA, Wall A, McGuire AT, Veesler D: Structure, Function, and Antigenicity of the SARS-CoV-2 Spike Glycoprotein. Cell 2020, 181(2):281-292 e286.

6. Lauer SA, Grantz KH, Bi Q, Jones FK, Zheng Q, Meredith HR, Azman AS, Reich NG, Lessler J: The Incubation Period of Coronavirus Disease 2019 (COVID-19) From Publicly Reported Confirmed Cases: Estimation and Application. Annals of internal medicine 2020, 172(9):577-582.

7. Cascella M, Rajnik M, Cuomo A, Dulebohn SC, Di Napoli R: Features, Evaluation and Treatment Coronavirus (COVID-19). In: StatPearls. Treasure Island (FL); 2020.

8. Yi Y, Lagniton PNP, Ye S, Li E, Xu RH: COVID-19: what has been learned and to be learned about the novel coronavirus disease. International journal of biological sciences 2020, 16(10):1753-1766.

9. Amanat F, Krammer F: SARS-CoV-2 Vaccines: Status Report. Immunity 2020, 52(4):583589.

10. Ouzzani M, Hammady H, Fedorowicz Z, Elmagarmid A. Rayyan-a web and mobile app for systematic reviews. Syst Rev 2016; 5.

11. Wells G, Shea B, O'Connell D, Peterson J. The Newcastle-Ottawa Scale (NOS) for assessing the quality of nonrandomised studies in meta-analyses. Ottawa, Ottawa Hosp. Res. Inst. 2000. http://www.ohri.ca/programs/clinical_epidemiology/oxford.asp.

12. Jadad AR, Moore RA, Carroll D, et al. Assessing the quality of reports of randomized clinical trials: Is blinding necessary? Control Clin Trials 1996; 17: 1-12 
medRxiv preprint doi: https://doi.org/10.1101/2020.05.23.20110965; this version posted May 26, 2020. The copyright holder for this preprint

(which was not certified by peer review) is the author/funder, who has granted medRxiv a license to display the preprint in perpetuity.

It is made available under a CC-BY-ND 4.0 International license .

13. Aggarwal S, Garcia-Telles N, Aggarwal G, Lavie C, Lippi G, Henry BM: Clinical features, laboratory characteristics, and outcomes of patients hospitalized with coronavirus disease 2019 (COVID-19): Early report from the United States. Diagnosis 2020, 7(2):9196.

14. Chu Y, Li T, Fang Q, Wang X: Clinical characteristics and imaging manifestations of the 2019 novel coronavirus disease (COVID-19): A multi-center study in Wenzhou city, Zhejiang, China. The Journal of infection 2020

15. Du RH, Liang LR, Yang CQ, Wang W, Cao TZ, Li M, Guo GY, Du J, Zheng CL, Zhu Q et al: Predictors of mortality for patients with COVID-19 pneumonia caused by SARSCoV-2: a prospective cohort study. The European respiratory journal 2020, 55(5).

16. Hong KS, Lee KH, Chung JH, Shin KC, Choi EY, Jin HJ, Jang JG, Lee W, Ahn JH: Clinical Features and Outcomes of 98 Patients Hospitalized with SARS-CoV-2 Infection in Daegu, South Korea: A Brief Descriptive Study. Yonsei medical journal 2020, 61(5):431437.

17. Javanian M, Bayani M, Shokri M, Sadeghi-Haddad-Zavareh M, Babazadeh A, Yeganeh B, Mohseni S, Mehraein R, Sepidarkish M, Bijani A et al: Clinical and laboratory findings from patients with COVID-19 pneumonia in Babol North of Iran: a retrospective cohort study. Romanian journal of internal medicine = Revue roumaine de medecine interne 2020.

18. Liang W, Liang H, Ou L, Chen B, Chen A, Li C, Li Y, Guan W, Sang L, Lu J et al: Development and Validation of a Clinical Risk Score to Predict the Occurrence of Critical Illness in Hospitalized Patients With COVID-19. JAMA internal medicine 2020.

19. Shi S, Qin M, Cai Y, Liu T, Shen B, Yang F, Cao S, Liu X, Xiang Y, Zhao Q et al: Characteristics and clinical significance of myocardial injury in patients with severe coronavirus disease 2019. European heart journal 2020.

20. Sun H, Ning R, Tao Y, Yu C, Deng X, Zhao C, Meng S, Tang F, Xu D: Risk Factors for Mortality in 244 Older Adults With COVID-19 in Wuhan, China: A Retrospective Study. Journal of the American Geriatrics Society 2020.

21. Sun L, Shen L, Fan J, Gu F, Hu M, An Y, Zhou Q, Fan H, Bi J: Clinical Features of Patients with Coronavirus Disease 2019 (COVID-19) from a Designated Hospital in Beijing, China. Journal of medical virology 2020. 
medRxiv preprint doi: https://doi.org/10.1101/2020.05.23.20110965; this version posted May 26, 2020. The copyright holder for this preprint

(which was not certified by peer review) is the author/funder, who has granted medRxiv a license to display the preprint in perpetuity.

It is made available under a CC-BY-ND 4.0 International license .

22. Tian S, Hu N, Lou J, Chen K, Kang X, Xiang Z, Chen H, Wang D, Liu N, Liu D et al: Characteristics of COVID-19 infection in Beijing. The Journal of infection 2020, 80(4):401-406.

23. Xiong F, Tang H, Liu L, Tu C, Tian JB, Lei CT, Liu J, Dong JW, Chen WL, Wang XH et al: Clinical Characteristics of and Medical Interventions for COVID-19 in Hemodialysis Patients in Wuhan, China. Journal of the American Society of Nephrology: JASN 2020.

24. Arentz M, Yim E, Klaff L, Lokhandwala S, Riedo FX, Chong M, Lee M: Characteristics and Outcomes of 21 Critically Ill Patients With COVID-19 in Washington State. Jama 2020 .

25. Bellosta R, Luzzani L, Natalini G, Pegorer MA, Attisani L, Cossu LG, Ferrandina C, Fossati A, Conti E, Bush RL et al: Acute limb ischemia in patients with COVID-19 pneumonia. Journal of vascular surgery 2020.

26. Bezzio C, Saibeni S, Variola A, Allocca M, Massari A, Gerardi V, Casini V, Ricci C, Zingone F, Amato A et al: Outcomes of COVID-19 in 79 patients with IBD in Italy: an IG-IBD study. Gut 2020.

27. Bhatraju PK, Ghassemieh BJ, Nichols M, Kim R, Jerome KR, Nalla AK, Greninger AL, Pipavath S, Wurfel MM, Evans L et al: Covid-19 in Critically Ill Patients in the Seattle Region - Case Series. The New England journal of medicine 2020.

28. Cai Q, Huang D, Ou P, Yu H, Zhu Z, Xia Z, Su Y, Ma Z, Zhang Y, Li Z et al: COVID-19 in a designated infectious diseases hospital outside Hubei Province, China. Allergy 2020.

29. Cai Y, Hao Z, Gao Y, Ping W, Wang Q, Peng S, Zhao B, Sun W, Zhu M, Li K et al: Coronavirus Disease 2019 in the Perioperative Period of Lung Resection: A Brief Report From a Single Thoracic Surgery Department in Wuhan, People's Republic of China. Journal of thoracic oncology : official publication of the International Association for the Study of Lung Cancer 2020.

30. Cao J, Tu WJ, Cheng W, Yu L, Liu YK, Hu X, Liu Q: Clinical Features and Short-term Outcomes of 102 Patients with Corona Virus Disease 2019 in Wuhan, China. Clinical infectious diseases : an official publication of the Infectious Diseases Society of America 2020.

31. Chen T, Wu D, Chen H, Yan W, Yang D, Chen G, Ma K, Xu D, Yu H, Wang H et al: Clinical characteristics of 113 deceased patients with coronavirus disease 2019: retrospective study. Bmj 2020, 368:m1091. 
medRxiv preprint doi: https://doi.org/10.1101/2020.05.23.20110965; this version posted May 26, 2020. The copyright holder for this preprint

(which was not certified by peer review) is the author/funder, who has granted medRxiv a license to display the preprint in perpetuity.

It is made available under a CC-BY-ND 4.0 International license.

32. Chen G, Wu D, Guo W, Cao Y, Huang D, Wang H, Wang T, Zhang X, Chen H, Yu H et al: Clinical and immunological features of severe and moderate coronavirus disease 2019. The Journal of clinical investigation 2020, 130(5):2620-2629.

33. Chen T, Dai Z, Mo P, Li X, Ma Z, Song S, Chen X, Luo M, Liang K, Gao S et al: Clinical characteristics and outcomes of older patients with coronavirus disease 2019 (COVID19) in Wuhan, China (2019): a single-centered, retrospective study. The journals of gerontology Series A, Biological sciences and medical sciences 2020.

34. Chen X, Zhao B, Qu Y, Chen Y, Xiong J, Feng Y, Men D, Huang Q, Liu Y, Yang B et al: Detectable serum SARS-CoV-2 viral load (RNAaemia) is closely correlated with drastically elevated interleukin 6 (IL-6) level in critically ill COVID-19 patients. Clinical infectious diseases : an official publication of the Infectious Diseases Society of America 2020

35. Chen Q, Zheng Z, Zhang C, Zhang X, Wu H, Wang J, Wang S, Zheng C: Clinical characteristics of 145 patients with corona virus disease 2019 (COVID-19) in Taizhou, Zhejiang, China. Infection 2020.

36. Yang W, Cao Q, Qin L, Wang X, Cheng Z, Pan A, Dai J, Sun Q, Zhao F, Qu J et al: Clinical characteristics and imaging manifestations of the 2019 novel coronavirus disease (COVID-19):A multi-center study in Wenzhou city, Zhejiang, China. The Journal of infection 2020, 80(4):388-393.

37. Colaneri M, Sacchi P, Zuccaro V, Biscarini S, Sachs M, Roda S, Pieri TC, Valsecchi P, Piralla A, Seminari E et al: Clinical characteristics of coronavirus disease (COVID-19) early findings from a teaching hospital in Pavia, North Italy, 21 to February 28 2020. Euro surveillance : bulletin Europeen sur les maladies transmissibles = European communicable disease bulletin 2020, 25(16).

38. Deng Q, Hu B, Zhang Y, Wang H, Zhou X, Hu W, Cheng Y, Yan J, Ping H, Zhou Q: Suspected myocardial injury in patients with COVID-19: Evidence from front-line clinical observation in Wuhan, China. International journal of cardiology 2020.

39. Deng Y, Liu W, Liu K, Fang YY, Shang J, Zhou L, Wang K, Leng F, Wei S, Chen L et al: Clinical characteristics of fatal and recovered cases of coronavirus disease 2019 (COVID-19) in Wuhan, China: a retrospective study. Chinese medical journal 2020.

40. Duanmu Y, Brown IP, Gibb WR, Singh J, Matheson LW, Blomkalns AL, Govindarajan P: Characteristics of Emergency Department Patients With COVID-19 at a Single Site in Northern California: Clinical Observations and Public Health Implications. Academic emergency medicine : official journal of the Society for Academic Emergency Medicine 2020. 
medRxiv preprint doi: https://doi.org/10.1101/2020.05.23.20110965; this version posted May 26, 2020. The copyright holder for this preprint

(which was not certified by peer review) is the author/funder, who has granted medRxiv a license to display the preprint in perpetuity.

It is made available under a CC-BY-ND 4.0 International license .

41. Feng Y, Ling Y, Bai T, Xie Y, Huang J, Li J, Xiong W, Yang D, Chen R, Lu F et al: COVID19 with Different Severity: A Multi-center Study of Clinical Features. American journal of respiratory and critical care medicine 2020.

42. Team TNCPERE: Vital Surveillances: The Epidemiological Characteristics of an Outbreak of 2019 Novel Coronavirus Diseases (COVID-19) - China, 2020. China CDC Weekly 2020, 2(8):113-122.

43. Goyal P, Choi JJ, Pinheiro LC, Schenck EJ, Chen R, Jabri A, Satlin MJ, Campion TR, Jr., Nahid M, Ringel JB et al: Clinical Characteristics of Covid-19 in New York City. The New England journal of medicine 2020.

44. Grasselli G, Zangrillo A, Zanella A, Antonelli M, Cabrini L, Castelli A, Cereda D, Coluccello A, Foti G, Fumagalli R et al: Baseline Characteristics and Outcomes of 1591 Patients Infected With SARS-CoV-2 Admitted to ICUs of the Lombardy Region, Italy. Jama 2020 .

45. Guan WJ, Ni ZY, Hu Y, Liang WH, Ou CQ, He JX, Liu L, Shan H, Lei CL, Hui DSC et al: Clinical Characteristics of Coronavirus Disease 2019 in China. The New England journal of medicine 2020, 382(18):1708-1720.

46. Guo T, Fan Y, Chen M, Wu X, Zhang L, He T, Wang H, Wan J, Wang X, Lu Z: Cardiovascular Implications of Fatal Outcomes of Patients With Coronavirus Disease 2019 (COVID-19). JAMA cardiology 2020.

47. He R, Lu Z, Zhang L, Fan T, Xiong R, Shen X, Feng H, Meng H, Lin W, Jiang W et al: The clinical course and its correlated immune status in COVID-19 pneumonia. Journal of clinical virology : the official publication of the Pan American Society for Clinical Virology 2020, 127:104361.

48. Hu H, Yao N, Qiu Y: Comparing rapid scoring systems in mortality prediction of critical ill patients with novel coronavirus disease. Academic emergency medicine : official journal of the Society for Academic Emergency Medicine 2020.

49. Huang C, Wang Y, Li X, Ren L, Zhao J, Hu Y, Zhang L, Fan G, Xu J, Gu X et al: Clinical features of patients infected with 2019 novel coronavirus in Wuhan, China. Lancet 2020, 395(10223):497-506.

50. Jacobs JP, Stammers AH, St Louis J, Hayanga JWA, Firstenberg MS, Mongero LB, Tesdahl EA, Rajagopal K, Cheema FH, Coley T et al: Extracorporeal Membrane Oxygenation in the Treatment of Severe Pulmonary and Cardiac Compromise in COVID-19: Experience with 32 patients. ASAIO journal 2020. 
medRxiv preprint doi: https://doi.org/10.1101/2020.05.23.20110965; this version posted May 26, 2020. The copyright holder for this preprint

(which was not certified by peer review) is the author/funder, who has granted medRxiv a license to display the preprint in perpetuity.

It is made available under a CC-BY-ND 4.0 International license.

51. Lei S, Jiang F, Su W, Chen C, Chen J, Mei W, Zhan LY, Jia Y, Zhang L, Liu D et al: Clinical characteristics and outcomes of patients undergoing surgeries during the incubation period of COVID-19 infection. EClinicalMedicine 2020:100331.

52. Li X, Xu S, Yu M, Wang K, Tao Y, Zhou Y, Shi J, Zhou M, Wu B, Yang Z et al: Risk factors for severity and mortality in adult COVID-19 inpatients in Wuhan. The Journal of allergy and clinical immunology 2020.

53. Li YK, Peng S, Li LQ, Wang Q, Ping W, Zhang N, Fu XN: Clinical and Transmission Characteristics of Covid-19 - A Retrospective Study of 25 Cases from a Single Thoracic Surgery Department. Current medical science 2020, 40(2):295-300.

54. Liu W, Tao ZW, Wang L, Yuan ML, Liu K, Zhou L, Wei S, Deng Y, Liu J, Liu HG et al: Analysis of factors associated with disease outcomes in hospitalized patients with 2019 novel coronavirus disease. Chinese medical journal 2020, 133(9):1032-1038.

55. Liu Y, Sun W, Li J, Chen L, Wang Y, Zhang L, Yu L: Clinical features and progression of acute respiratory distress syndrome in coronavirus disease 2019. medRxiv 2020:1-28.

56. Liu Y, Du X, Chen J, Jin Y, Peng L, Wang HHX, Luo M, Chen L, Zhao Y: Neutrophil-tolymphocyte ratio as an independent risk factor for mortality in hospitalized patients with COVID-19. The Journal of infection 2020.

57. Liu F, Li L, Xu M, Wu J, Luo D, Zhu Y, Li B, Song X, Zhou X: Prognostic value of interleukin-6, C-reactive protein, and procalcitonin in patients with COVID-19. Journal of clinical virology: the official publication of the Pan American Society for Clinical Virology 2020, 127:104370.

58. Liu J, Li S, Liu J, Liang B, Wang X, Wang H, Li W, Tong Q, Yi J, Zhao L et al: Longitudinal characteristics of lymphocyte responses and cytokine profiles in the peripheral blood of SARS-CoV-2 infected patients. EBioMedicine 2020, 55:102763.

59. Lodigiani C, Iapichino G, Carenzo L, Cecconi M, Ferrazzi P, Sebastian T, Kucher N, Studt JD, Sacco C, Alexia B et al: Venous and arterial thromboembolic complications in COVID-19 patients admitted to an academic hospital in Milan, Italy. Thrombosis research 2020, 191:9-14.

60. Lyu P, Liu X, Zhang R, Shi L, Gao J: The performance of chest CT in evaluating the clinical severity of COVID-19 pneumonia: identifying critical cases based on CT characteristics. Investigative radiology 2020.

61. Meng H, Xiong R, He R, Lin W, Hao B, Zhang L, Lu Z, Shen X, Fan T, Jiang W et al: CT imaging and clinical course of asymptomatic cases with COVID-19 pneumonia at admission in Wuhan, China. The Journal of infection 2020. 
medRxiv preprint doi: https://doi.org/10.1101/2020.05.23.20110965; this version posted May 26, 2020. The copyright holder for this preprint

(which was not certified by peer review) is the author/funder, who has granted medRxiv a license to display the preprint in perpetuity.

It is made available under a CC-BY-ND 4.0 International license.

62. Meng Y, Wu P, Lu W, Liu K, Ma K, Huang L, Cai J, Zhang H, Qin Y, Sun H et al: Sexspecific clinical characteristics and prognosis of coronavirus disease-19 infection in Wuhan, China: A retrospective study of 168 severe patients. PLoS pathogens 2020, 16(4):e1008520.

63. Mo P, Xing Y, Xiao Y, Deng L, Zhao Q, Wang H, Xiong Y, Cheng Z, Gao S, Liang K et al: Clinical characteristics of refractory COVID-19 pneumonia in Wuhan, China. Clinical infectious diseases : an official publication of the Infectious Diseases Society of America 2020 .

64. Niu S, Tian S, Lou J, Kang X, Zhang L, Lian H, Zhang J: Clinical characteristics of older patients infected with COVID-19: A descriptive study. Archives of gerontology and geriatrics 2020, 89:104058.

65. Onder G, Rezza G, Brusaferro S: Case-Fatality Rate and Characteristics of Patients Dying in Relation to COVID-19 in Italy. Jama 2020.

66. Pan L, Mu M, Yang P, Sun Y, Wang R, Yan J, Li P, Hu B, Wang J, Hu C et al: Clinical Characteristics of COVID-19 Patients With Digestive Symptoms in Hubei, China: A Descriptive, Cross-Sectional, Multicenter Study. The American journal of gastroenterology 2020, 115(5):766-773.

67. Peng S, Huang L, Zhao B, Zhou S, Braithwaite I, Zhang N, Fu X: Clinical course of coronavirus disease 2019 in 11 patients after thoracic surgery and challenges in diagnosis. The Journal of Thoracic and Cardiovascular Surgery 2020.

68. Peng YD, Meng K, Guan HQ, Leng L, Zhu RR, Wang BY, He MA, Cheng LX, Huang K, Zeng QT: [Clinical characteristics and outcomes of 112 cardiovascular disease patients infected by 2019-nCoV]. Zhonghua xin xue guan bing za zhi 2020, 48(0):E004.

69. Pereira MR, Mohan S, Cohen DJ, Husain SA, Dube GK, Ratner LE, Arcasoy S, Aversa MM, Benvenuto LJ, Dadhania DM et al: COVID-19 in solid organ transplant recipients: Initial report from the US epicenter. American journal of transplantation : official journal of the American Society of Transplantation and the American Society of Transplant Surgeons 2020.

70. Richardson S, Hirsch JS, Narasimhan M, Crawford JM, McGinn T, Davidson KW, and the Northwell C-RC, Barnaby DP, Becker LB, Chelico JD et al: Presenting Characteristics, Comorbidities, and Outcomes Among 5700 Patients Hospitalized With COVID-19 in the New York City Area. Jama 2020.

71. Shi Y, Yu X, Zhao H, Wang H, Zhao R, Sheng J: Host susceptibility to severe COVID-19 and establishment of a host risk score: findings of 487 cases outside Wuhan. Critical care 2020, 24(1):108. 
medRxiv preprint doi: https://doi.org/10.1101/2020.05.23.20110965; this version posted May 26, 2020. The copyright holder for this preprint

(which was not certified by peer review) is the author/funder, who has granted medRxiv a license to display the preprint in perpetuity.

It is made available under a CC-BY-ND 4.0 International license .

72. Tian S, Hu N, Lou J, Chen K, Kang X, Xiang Z, Chen H, Wang D, Liu N, Liu D et al: Characteristics of COVID-19 infection in Beijing. Journal of Infection 2020, 80(4):401406.

73. Wan S, Xiang Y, Fang W, Zheng Y, Li B, Hu Y, Lang C, Huang D, Sun Q, Xiong Y et al: Clinical features and treatment of COVID-19 patients in northeast Chongqing. Journal of medical virology 2020.

74. Wang D, Hu B, Hu C, Zhu F, Liu X, Zhang J, Wang B, Xiang H, Cheng Z, Xiong Y et al: Clinical Characteristics of 138 Hospitalized Patients With 2019 Novel CoronavirusInfected Pneumonia in Wuhan, China. Jama 2020.

75. Wang $\mathrm{L}, \mathrm{He} \mathrm{W}, \mathrm{Yu} \mathrm{X}, \mathrm{Hu} \mathrm{D}, \mathrm{Bao} \mathrm{M}$, Liu H, Zhou J, Jiang H: Coronavirus disease 2019 in elderly patients: Characteristics and prognostic factors based on 4-week follow-up. The Journal of infection 2020.

76. Wang R, Pan M, Zhang X, Han M, Fan X, Zhao F, Miao M, Xu J, Guan M, Deng X et al: Epidemiological and clinical features of 125 Hospitalized Patients with COVID-19 in Fuyang, Anhui, China. International journal of infectious diseases : IJID : official publication of the International Society for Infectious Diseases 2020, 95:421-428.

77. Wang X, Fang J, Zhu Y, Chen L, Ding F, Zhou R, Ge L, Wang F, Chen Q, Zhang Y et al: Clinical characteristics of non-critically ill patients with novel coronavirus infection (COVID-19) in a Fangcang Hospital. Clinical microbiology and infection : the official publication of the European Society of Clinical Microbiology and Infectious Diseases 2020.

78. Wang F, Yang Y, Dong K, Yan Y, Zhang S, Ren H, Yu X, Shi X: Clinical Characteristics of 28 Patients with Diabetes and Covid-19 in Wuhan, China. Endocrine practice : official journal of the American College of Endocrinology and the American Association of Clinical Endocrinologists 2020.

79. Wang M, Guo L, Chen Q, Xia G, Wang B: Typical radiological progression and clinical features of patients with coronavirus disease 2019. Aging 2020, 12.

80. Wu C, Chen X, Cai Y, Xia J, Zhou X, Xu S, Huang H, Zhang L, Zhou X, Du C et al: Risk Factors Associated With Acute Respiratory Distress Syndrome and Death in Patients With Coronavirus Disease 2019 Pneumonia in Wuhan, China. JAMA internal medicine 2020 .

81. Wu J, Li W, Shi X, Chen Z, Jiang B, Liu J, Wang D, Liu C, Meng Y, Cui L et al: Early antiviral treatment contributes to alleviate the severity and improve the prognosis of patients with novel coronavirus disease (COVID-19). Journal of internal medicine 2020. 
medRxiv preprint doi: https://doi.org/10.1101/2020.05.23.20110965; this version posted May 26, 2020. The copyright holder for this preprint

(which was not certified by peer review) is the author/funder, who has granted medRxiv a license to display the preprint in perpetuity.

It is made available under a CC-BY-ND 4.0 International license.

82. Xie H, Zhao J, Lian N, Lin S, Xie Q, Zhuo H: Clinical characteristics of non-ICU hospitalized patients with coronavirus disease 2019 and liver injury: A retrospective study. Liver international : official journal of the International Association for the Study of the Liver 2020.

83. Xie J, Ding C, Li J, Wang Y, Guo H, Lu Z, Wang J, Zheng C, Jin T, Gao Y et al: Characteristics of patients with coronavirus disease (COVID-19) confirmed using an IgM-IgG antibody test. Journal of medical virology 2020.

84. Yan Y, Yang Y, Wang F, Ren H, Zhang S, Shi X, Yu X, Dong K: Clinical characteristics and outcomes of patients with severe covid-19 with diabetes. BMJ open diabetes research \& care $2020,8(1)$.

85. Yang X, Yu Y, Xu J, Shu H, Xia J, Liu H, Wu Y, Zhang L, Yu Z, Fang M et al: Clinical course and outcomes of critically ill patients with SARS-CoV-2 pneumonia in Wuhan, China: a single-centered, retrospective, observational study. The Lancet Respiratory medicine 2020, 8(5):475-481.

86. Yang F, Shi S, Zhu J, Shi J, Dai K, Chen X: Clinical characteristics and outcomes of cancer patients with COVID-19. Journal of medical virology 2020.

87. Wang Y, Shi L, Yang H, Duan G, Wang Y: Acute kidney injury is associated with the mortality of Coronavirus Disease 2019. Journal of medical virology 2020.

88. Yang Y, Shen C, Li J, Yuan J, Wei J, Huang F, Wang F, Li G, Li Y, Xing L et al: Plasma IP10 and MCP-3 levels are highly associated with disease severity and predict the progression of COVID-19. The Journal of allergy and clinical immunology 2020.

89. Yao Q, Wang P, Wang X, Qie G, Meng M, Tong X, Bai X, Ding M, Liu W, Liu K et al: Retrospective study of risk factors for severe SARS-Cov-2 infections in hospitalized adult patients. Polish archives of internal medicine 2020.

90. Yu X, Sun X, Cui P, Pan H, Lin S, Han R, Jiang C, Fang Q, Kong D, Zhu Y et al: Epidemiological and clinical characteristics of 333 confirmed cases with coronavirus disease 2019 in Shanghai, China. Transboundary and emerging diseases 2020.

91. Yuan M, Yin W, Tao Z, Tan W, Hu Y: Association of radiologic findings with mortality of patients infected with 2019 novel coronavirus in Wuhan, China. PloS one 2020, 15(3): 0230548 .

92. Zhang JJ, Dong X, Cao YY, Yuan YD, Yang YB, Yan YQ, Akdis CA, Gao YD: Clinical characteristics of 140 patients infected with SARS-CoV-2 in Wuhan, China. Allergy 2020 . 
medRxiv preprint doi: https://doi.org/10.1101/2020.05.23.20110965; this version posted May 26, 2020. The copyright holder for this preprint

(which was not certified by peer review) is the author/funder, who has granted medRxiv a license to display the preprint in perpetuity.

It is made available under a CC-BY-ND 4.0 International license .

93. Zhang J, Yu M, Tong S, Liu LY, Tang LV: Predictive factors for disease progression in hospitalized patients with coronavirus disease 2019 in Wuhan, China. Journal of clinical virology : the official publication of the Pan American Society for Clinical Virology 2020, 127:104392.

94. Zhao XY, Xu XX, Yin HS, Hu QM, Xiong T, Tang YY, Yang AY, Yu BP, Huang ZP: Clinical characteristics of patients with 2019 coronavirus disease in a non-Wuhan area of Hubei Province, China: a retrospective study. BMC infectious diseases 2020, 20(1):311.

95. Zheng F, Tang W, Li H, Huang YX, Xie YL, Zhou ZG: Clinical characteristics of 161 cases of corona virus disease 2019 (COVID-19) in Changsha. European review for medical and pharmacological sciences 2020, 24(6):3404-3410.

96. Zheng S, Fan J, Yu F, Feng B, Lou B, Zou Q, Xie G, Lin S, Wang R, Yang X et al: Viral load dynamics and disease severity in patients infected with SARS-CoV-2 in Zhejiang province, China, January-March 2020: retrospective cohort study. Bmj 2020, 369:m1443.

97. Zhou F, Yu T, Du R, Fan G, Liu Y, Liu Z, Xiang J, Wang Y, Song B, Gu X et al: Clinical course and risk factors for mortality of adult inpatients with COVID-19 in Wuhan, China: a retrospective cohort study. Lancet 2020, 395(10229):1054-1062.

98. Zhou Y, Han T, Chen J, Hou C, Hua L, He S, Guo Y, Zhang S, Wang Y, Yuan J et al: Clinical and Autoimmune Characteristics of Severe and Critical Cases of COVID-19. Clinical and translational science 2020.

99. Guarner J: Three Emerging Coronaviruses in Two Decades. American journal of clinical pathology 2020, 153(4):420-421.

100. Jaillon S, Berthenet K, Garlanda C: Sexual Dimorphism in Innate Immunity. Clinical reviews in allergy \& immunology 2019, 56(3):308-321.

101. Badawi A, Ryoo SG: Prevalence of comorbidities in the Middle East respiratory syndrome coronavirus (MERS-CoV): a systematic review and meta-analysis. International journal of infectious diseases : IJID : official publication of the International Society for Infectious Diseases 2016, 49:129-133.

102. Channappanavar R, Fett C, Mack M, Ten Eyck PP, Meyerholz DK, Perlman S: Sex-Based Differences in Susceptibility to Severe Acute Respiratory Syndrome Coronavirus Infection. Journal of immunology 2017, 198(10):4046-4053.

103. Landi F, Barillaro C, Bellieni A, Brandi V, Carfi A, D'Angelo M, Fusco D, Landi G, Lo Monaco R, Martone AM et al: The New Challenge of Geriatrics: Saving Frail Older 
medRxiv preprint doi: https://doi.org/10.1101/2020.05.23.20110965; this version posted May 26, 2020. The copyright holder for this preprint (which was not certified by peer review) is the author/funder, who has granted medRxiv a license to display the preprint in perpetuity. It is made available under a CC-BY-ND 4.0 International license .

People from the SARS-COV-2 Pandemic Infection. The journal of nutrition, health \& aging 2020, 24(5):466-470.

104. Yang J, Zheng Y, Gou X, Pu K, Chen Z, Guo Q, Ji R, Wang H, Wang Y, Zhou Y: Prevalence of comorbidities and its effects in coronavirus disease 2019 patients: A systematic review and meta-analysis. International journal of infectious diseases : IJID : official publication of the International Society for Infectious Diseases 2020, 94:91-95.

105. Odegaard JI, Chawla A: Connecting type 1 and type 2 diabetes through innate immunity. Cold Spring Harbor perspectives in medicine 2012, 2(3):a007724.

106. Alraddadi BM, Watson JT, Almarashi A, Abedi GR, Turkistani A, Sadran M, Housa A, Almazroa MA, Alraihan N, Banjar A et al: Risk Factors for Primary Middle East Respiratory Syndrome Coronavirus Illness in Humans, Saudi Arabia, 2014. Emerging infectious diseases 2016, 22(1):49-55.

107. Fu L, Wang B, Yuan T, Chen X, Ao Y, Fitzpatrick T, Li P, Zhou Y, Lin YF, Duan Q et al: Clinical characteristics of coronavirus disease 2019 (COVID-19) in China: A systematic review and meta-analysis. The Journal of infection 2020.

\section{Figure legends}

Figure 1. Flow diagram for selection of studies for inclusion in this meta-analysis

Figure 2. Pooled effects of sex on COVID-19-linked death. All the studies reported death as a clinical outcome except the Guan G where the outcome was recorded as a primary composite endpoint consisting of death, admission to an intensive care unit or use of mechanical ventilation.

Figure 3. Pooled effects of age on COVID-19-linked death (age $\geq 50$ Vs. age $<50$ years)

Figure 4. Pooled effects of comorbidities on the death linked with COVID-19

Figure 5. Pooled effects of clinical symptoms on the death linked with COVID-19

Figure 6. Mortality and survivors linked with COVID-19

Figure 7. Sensitivity analysis of the effect of sex on the severity of COVID-19.

Figure 8. Funnel plot for the detection of publication bias 
Table 1. Baseline characteristics of included studies

\begin{tabular}{|c|c|c|c|c|c|c|c|}
\hline Study ID & Year & Country & Study Design & $\begin{array}{l}\text { Sample } \\
\text { Size }\end{array}$ & Male (\%) & $\begin{array}{l}\text { Median Age/ } \\
\text { Mean } \pm \text { SD }\end{array}$ & $\begin{array}{c}\text { Follow- } \\
\text { up/Observation } \\
\text { period/Data } \\
\text { collection } \\
\text { period, } \\
\text { days }\end{array}$ \\
\hline Aggarwal S & 2020 & USA & retrospective study & 7 & $12(75 \%)$ & $67 / 65.5$ & 36 \\
\hline Arentz M & 2020 & USA & retrospective study & 21 & $11(52 \%)$ & 70 & 14 \\
\hline Bellosta R & 2020 & Italy & $\begin{array}{l}\text { single center, } \\
\text { observational } \\
\text { cohort study. }\end{array}$ & 20 & $18(90 \%)$ & $75 \pm 9$ & --- \\
\hline Bezzio C & 2020 & Italy & $\begin{array}{l}\text { prospective } \\
\text { observational } \\
\text { cohort study }\end{array}$ & 79 & $44(557.7 \%)$ & 45 & 18 \\
\hline Bhatraju PK & 2020 & USA & retrospective study & 24 & $15(63 \%)$ & $64 \pm 18$ & 13 \\
\hline Cai Q & 2020 & China & retrospective study & 298 & $145(48.66 \%)$ & 47.5 & 55 \\
\hline Cai Y & 2020 & China & retrospective study & 7 & $5(71.43 \%)$ & 60.29 & $\begin{array}{ll}----- \\
\end{array}$ \\
\hline Cao J & 2020 & China & retrospective study & 102 & $53(52 \%)$ & 54 & 30 \\
\hline Chen T & 2020 & China & retrospective study & 274 & $171(62 \%)$ & 62 & 30 \\
\hline Chen $\mathrm{G}$ & 2020 & China & retrospective study & 21 & $17(81 \%)$ & 56 & ----- \\
\hline Chen T Dai Z & 2020 & China & $\begin{array}{l}\text { a single-centered, } \\
\text { retrospective study }\end{array}$ & 203 & $108(53.2 \%)$ & 54 & 41 \\
\hline Chen X & 2020 & China & retrospective study & 48 & $37(77.1 \%)$ & $64.6 \pm 18.1$ & 19 \\
\hline Chen Q & 2020 & China & $\begin{array}{c}\text { single center } \\
\text { retrospective } \\
\text { observational study }\end{array}$ & 145 & $79(54.5 \%)$ & 47.5 & 71 \\
\hline Chu Y & 2020 & China & $\begin{array}{c}\text { single center } \\
\text { retrospective } \\
\text { observational study }\end{array}$ & 33 & $22(66.7 \%)$ & $65.2 \pm 16.6$ & 29 \\
\hline Colaneri $\mathrm{M}$ & 2020 & Italy & retrospective study & 44 & $28(63.64 \%)$ & 67.5 & 13 \\
\hline Deng Q & 2020 & China & retrospective study & 112 & $57(50.9 \%)$ & 65.0 & 45 \\
\hline
\end{tabular}




\begin{tabular}{|c|c|c|c|c|c|c|c|}
\hline Deng $\mathrm{Y}$ & 2020 & China & retrospective study & 225 & $124(55.11 \%)$ & 54.5 & 52 \\
\hline Duanmu Y & 2020 & USA & retrospective study & 100 & $56(56 \%)$ & 45.0 & 19 \\
\hline Du RH & 2020 & China & $\begin{array}{c}\text { prospective cohort } \\
\text { study }\end{array}$ & 179 & $97(54.2)$ & $57.6 \pm 13.7$ & 13 \\
\hline Feng Y & 2020 & China & $\begin{array}{c}\text { multi-center } \\
\text { retrospective study }\end{array}$ & 476 & $271(56.9 \%)$ & 53.0 & 46 \\
\hline Goyal P & 2020 & USA & retrospective study & 393 & $238(60.6 \%)$ & 62.2 & 24 \\
\hline Grasselli G & 2020 & Italy & retrospective study & 1591 & $1304(82 \%)$ & 63.0 & 34 \\
\hline Guan WJ & 2020 & China & retrospective study & 1099 & $637(57.96 \%)$ & 47.0 & 49 \\
\hline Guo $\mathrm{T}$ & 2020 & China & $\begin{array}{c}\text { single center } \\
\text { retrospective study }\end{array}$ & 187 & $91(48.7 \%)$ & 58.50 & 31 \\
\hline He R & 2020 & China & retrospective study & 204 & $79(38.73 \%)$ & 49.0 & 34 \\
\hline Hong KS & 2020 & $\begin{array}{l}\text { South } \\
\text { Korea }\end{array}$ & Descriptive Study & 98 & $38(38.8 \%)$ & $55.4 \pm 17.1$ & 90 \\
\hline $\mathrm{Hu} \mathrm{H}$ & 2020 & China & retrospective study & 105 & $54(50.94 \%)$ & $60.82 \pm 16.32$ & 29 \\
\hline Huang C & 2020 & China & prospective study & 41 & $30(73 \%)$ & 49.0 & 17 \\
\hline Jacobs JP & 2020 & USA & $\begin{array}{c}\text { real time cohort } \\
\text { study }\end{array}$ & 32 & $22(68.8 \%)$ & 52.41 & 24 \\
\hline Javanian M & 2020 & Iran & $\begin{array}{c}\text { retrospective cohort } \\
\text { study }\end{array}$ & 100 & $51(51 \%)$ & 60.12 & 21 \\
\hline Lei $\mathrm{S}$ & 2020 & China & retrospective study & 34 & $14(41.2 \%)$ & 55.0 & 36 \\
\hline Li X & 2020 & China & retrospective study & 548 & $279(50.9 \%)$ & 60.0 & 37 \\
\hline Li YK & 2020 & China & retrospective study & 25 & $13(52 \%)$ & 61 & 51 \\
\hline Liang W & 2020 & China & retrospective study & 1590 & $904(57.4 \%)$ & 48.9 & 26 \\
\hline Liu W & 2020 & China & retrospective study & 78 & $39(50.0 \%)$ & 38.0 & 17 \\
\hline Liu Y & 2020 & China & retrospective study & 109 & $59(54.1 \%)$ & 55.0 & 41 \\
\hline Liu Y Du X & 2020 & China & retrospective study & 245 & $114(46.53 \%)$ & 53.95 & 60 \\
\hline Liu F & 2020 & China & retrospective study & 140 & $49(35.0 \%)$ & 65.5 & 54 \\
\hline Liu J & 2020 & China & $\begin{array}{c}\text { retrospective } \\
\text { single-center study }\end{array}$ & 40 & $15(37.5 \%)$ & $48.7 \pm 13.9$ & 19 \\
\hline Lodigiani C & 2020 & Italy & retrospective study & 388 & $264(68 \%)$ & 66.0 & 57 \\
\hline Lyu P & 2020 & China & retrospective study & 51 & $29(56.86 \%)$ & $54 \pm 17$ & 40 \\
\hline Meng $\mathrm{H}$ & 2020 & China & retrospective study & 58 & $26(44.8 \%)$ & $42.60 \pm 16.56$ & 54 \\
\hline
\end{tabular}




\begin{tabular}{|c|c|c|c|c|c|c|c|}
\hline Meng Y & 2020 & China & retrospective study & 168 & $86(51.19 \%)$ & 56.7 & 19 \\
\hline Mo P & 2020 & China & $\begin{array}{c}\text { retrospective } \\
\text { single-center study }\end{array}$ & 155 & $86(55.5 \%)$ & 54.0 & 36 \\
\hline Niu S & 2020 & China & descriptive Study & 141 & $70(49.65 \%)$ & 70.0 & 40 \\
\hline Onder $\mathrm{G}$ & 2020 & Italy & --------- & 355 & $249(70 \%)$ & 79.5 & ------- \\
\hline Pan L & 2020 & China & $\begin{array}{c}\text { a descriptive, cross- } \\
\text { sectional, } \\
\text { multicenter study }\end{array}$ & 204 & $107(52.45 \%)$ & $52.9 \pm 16$ & 60 \\
\hline Peng $\mathrm{S}$ & 2020 & China & retrospective study & 11 & $8(72.7 \%)$ & 61.0 & 24 \\
\hline Peng YD & 2020 & China & retrospective study & 112 & $53(47.32 \%)$ & 62.0 & 26 \\
\hline Pereira MR & 2020 & USA & retrospective study & 90 & $53(59 \%)$ & 57.0 & 20 \\
\hline Richardson S & 2020 & USA & retrospective study & 5700 & $3437(60.3 \%)$ & 63.0 & 35 \\
\hline Shi S & 2020 & China & retrospective study & 671 & $322(48.0 \%)$ & 63.0 & 54 \\
\hline Shi H & 2020 & China & retrospective study & 81 & $42(52 \%)$ & 49.5 & 33 \\
\hline Shi Y & 2020 & China & retrospective study & 487 & $259(53.2 \%)$ & 46.0 & 15 \\
\hline Sun $\mathrm{H}$ & 2020 & China & retrospective study & 244 & $133(54.51 \%)$ & 69.5 & 36 \\
\hline Sun L & 2020 & China & retrospective study & 55 & $31(56.4 \%)$ & 44.0 & 26 \\
\hline Team NCPERE & 2020 & China & $\begin{array}{l}\text { descriptive, } \\
\text { exploratory study }\end{array}$ & 44672 & $\begin{array}{c}22,981 \\
(51.4 \%)\end{array}$ & -------- & 43 \\
\hline Tian $\mathrm{S}$ & 2020 & China & retrospective study & 262 & $127(48.5 \%)$ & 47.5 & 21 \\
\hline Wan S & 2020 & China & retrospective study & 135 & $72(53.3 \%)$ & 47 & 16 \\
\hline Wang D & 2020 & China & $\begin{array}{c}\text { retrospective } \\
\text { single-center study }\end{array}$ & 138 & $75(54.3 \%)$ & 56 & 34 \\
\hline Wang L & 2020 & China & $\begin{array}{c}\text { retrospective } \\
\text { single-center study }\end{array}$ & 339 & $166(48.97 \%)$ & 69.0 & 37 \\
\hline Wang $\mathrm{R}$ & 2020 & China & $\begin{array}{l}\text { single-center, } \\
\text { retrospective, } \\
\text { descriptive study }\end{array}$ & 125 & $54(43.2 \%)$ & $38.76 \pm 13.80$ & 29 \\
\hline Wang X & 2020 & China & retrospective study & 1012 & $524(51.8 \%)$ & 50.0 & 15 \\
\hline Wang $\mathrm{F}$ & 2020 & China & retrospective study & 28 & $21(75.0 \%)$ & $68.6 \pm 9.0$ & 24 \\
\hline Wang M & 2020 & China & retrospective study & 66 & $43(65 \%)$ & 44.0 & 12 \\
\hline $\mathrm{Wu} \mathrm{C}$ & 2020 & China & retrospective study & 201 & $128(63.7 \%)$ & 51.0 & 31 \\
\hline $\mathrm{Wu} \mathrm{J}$ & 2020 & China & retrospective study & 280 & $151(53.93 \%)$ & $\begin{array}{c}43.12 \pm \\
19.02 \\
\end{array}$ & 31 \\
\hline
\end{tabular}




\begin{tabular}{|c|c|c|c|c|c|c|c|}
\hline $\mathrm{Xie} \mathrm{H}$ & 2020 & China & retrospective study & 79 & $44(55.7 \%)$ & 60.0 & 21 \\
\hline Xie J & 2020 & China & retrospective study & 56 & $24(42.86 \%)$ & 56.5 & 10 \\
\hline Xiong F & 2020 & China & retrospective study & 131 & $75(57.3 \%)$ & 63.3 & 70 \\
\hline Yan Y & 2020 & China & $\begin{array}{l}\text { single-center, } \\
\text { retrospective, } \\
\text { observational study }\end{array}$ & 193 & $114(59.1 \%)$ & 64.0 & 45 \\
\hline Yang X & 2020 & China & $\begin{array}{l}\text { a single-centered, } \\
\text { retrospective, } \\
\text { observational study }\end{array}$ & 52 & $35(67 \%)$ & 59.7 & 28 \\
\hline Yang Fa & 2020 & China & retrospective study & 52 & $28(53.8 \%)$ & 63.0 & 106 \\
\hline Yang $\mathrm{Fb}$ & 2020 & China & retrospective study & 92 & $49(53.3 \%)$ & $69.8 \pm 14.5$ & 50 \\
\hline Yang $\mathrm{Y}$ & 2020 & China & retrospective study & 50 & $29(58 \%)$ & 62.0 & 39 \\
\hline Yao Q & 2020 & China & retrospective study & 108 & $43(39.8 \%)$ & 52.0 & 12 \\
\hline $\mathrm{YuX}$ & 2020 & China & descriptive study & 333 & $172(51.7 \%)$ & 56.0 & 26 \\
\hline Yuan M & 2020 & China & descriptive study & 27 & $12(45 \%)$ & 60.0 & 25 \\
\hline Zhang JJ & 2020 & China & descriptive study & 140 & $71(50.7 \%)$ & 57.0 & 18 \\
\hline Zhang J & 2020 & China & $\begin{array}{c}\text { retrospective } \\
\text { single-center study }\end{array}$ & 111 & $46(41.44 \%)$ & 38.0 & 35 \\
\hline Zheng F & 2020 & China & descriptive study & 161 & $80(49.7 \%)$ & 45.0 & 21 \\
\hline Zheng S & 2020 & China & retrospective study & 96 & $58(60 \%)$ & 55.0 & 61 \\
\hline Zhou F & 2020 & China & retrospective study & 191 & $119(62 \%)$ & 56.0 & 34 \\
\hline Zhou Y & 2020 & China & retrospective study & 21 & $13(61.90 \%)$ & $66.10 \pm 13.94$ & 34 \\
\hline Zhao XY & 2020 & China & retrospective study & 91 & $49(46.7 \%)$ & 46.0 & 25 \\
\hline
\end{tabular}


Table 2. Quality assessment of the included observational studies by NOS

\begin{tabular}{|c|c|c|c|c|c|c|c|c|c|c|c|}
\hline \multirow[b]{3}{*}{ Author } & \multirow[b]{3}{*}{ Year } & \multicolumn{4}{|c|}{ Selection } & \multicolumn{2}{|c|}{ Comparability } & \multicolumn{3}{|c|}{ Outcome } & \multirow[b]{3}{*}{$\begin{array}{l}\text { Total } \\
\text { Score }\end{array}$} \\
\hline & & 1 & 2 & 3 & 4 & $5 \mathrm{~A}$ & $5 B$ & 6 & 7 & 8 & \\
\hline & & $\begin{array}{l}\text { Exposed cohort } \\
\text { truly/somewhat } \\
\text { representative }\end{array}$ & $\begin{array}{l}\text { Nonexposed } \\
\text { cohort } \\
\text { drawn from } \\
\text { the same } \\
\text { community }\end{array}$ & $\begin{array}{l}\text { Ascertainment } \\
\text { of exposure }\end{array}$ & $\begin{array}{l}\text { Outcome } \\
\text { of } \\
\text { interest } \\
\text { not } \\
\text { present } \\
\text { at start }\end{array}$ & $\begin{array}{l}\text { Cohorts } \\
\text { adjusted } \\
\text { for age }\end{array}$ & $\begin{array}{l}\text { Cohorts } \\
\text { adjusted } \\
\text { for other } \\
\text { important } \\
\text { factor(s) }\end{array}$ & $\begin{array}{l}\text { Quality of } \\
\text { outcome } \\
\text { assessment }\end{array}$ & $\begin{array}{l}\text { Follow-up/ } \\
\text { Observation } \\
\text { period } \\
\text { Long } \\
\text { enough for } \\
\text { outcomes to } \\
\text { occur }\end{array}$ & $\begin{array}{l}\text { Adequacy } \\
\text { of follow- } \\
\text { up of } \\
\text { cohorts }\end{array}$ & \\
\hline Aggarwal S & 2020 & $*$ & $*$ & $*$ & $*$ & $*$ & & $*$ & $*$ & - & 7 \\
\hline Arentz M & 2020 & $*$ & $*$ & $*$ & $*$ & & & $*$ & $*$ & - & 6 \\
\hline Bellosta R & 2020 & $*$ & - & $*$ & $*$ & $*$ & & $*$ & $*$ & - & 6 \\
\hline Bezzio C & 2020 & $*$ & $*$ & $*$ & $*$ & $*$ & $*$ & $*$ & $*$ & - & 8 \\
\hline Bhatraju PK & 2020 & $*$ & - & $*$ & $*$ & $*$ & & $*$ & $*$ & - & 6 \\
\hline Cai Q & 2020 & $*$ & - & $*$ & $*$ & & $*$ & $*$ & $*$ & $*$ & 7 \\
\hline Cai Y & 2020 & $*$ & - & $*$ & $*$ & $*$ & $*$ & $*$ & $*$ & $*$ & 8 \\
\hline Cao J & 2020 & $*$ & - & $*$ & $*$ & & & $*$ & $*$ & $*$ & 6 \\
\hline Chen T & 2020 & $*$ & & $*$ & $*$ & & & $*$ & $*$ & $*$ & 6 \\
\hline Chen $\mathrm{G}$ & 2020 & $*$ & $*$ & & $*$ & & & $*$ & $*$ & $*$ & 7 \\
\hline $\begin{array}{c}\text { Chen T Dai } \\
\text { Z }\end{array}$ & 2020 & $*$ & & $*$ & $*$ & & & $*$ & $*$ & $*$ & 6 \\
\hline Chen X & 2020 & $*$ & $*$ & & $*$ & $*$ & & $*$ & $*$ & & 6 \\
\hline Chen Q & 2020 & $*$ & $*$ & $*$ & $*$ & & & $*$ & $*$ & & 6 \\
\hline Chu Y & 2020 & $*$ & $*$ & $*$ & $*$ & & & $*$ & $*$ & $*$ & 7 \\
\hline Colaneri M & 2020 & $*$ & & $*$ & $*$ & & $*$ & $*$ & $*$ & $*$ & 7 \\
\hline Deng Q & 2020 & $*$ & & $*$ & $*$ & & & $*$ & $*$ & $*$ & 6 \\
\hline Deng Y & 2020 & $*$ & $*$ & $*$ & $*$ & & $*$ & $*$ & $*$ & $*$ & 8 \\
\hline Duanmu Y & 2020 & $*$ & $*$ & $*$ & $*$ & & & $*$ & $*$ & & 6 \\
\hline $\mathrm{Du}$ RH & 2020 & $*$ & $*$ & $*$ & $*$ & & & $*$ & $*$ & & 6 \\
\hline Feng $\mathrm{Y}$ & 2020 & $*$ & & $*$ & $*$ & & & $*$ & $*$ & $*$ & 6 \\
\hline Goyal P & 2020 & $*$ & & $*$ & $*$ & $*$ & & $*$ & $*$ & & 6 \\
\hline Grasselli G & 2020 & $*$ & $*$ & $*$ & $*$ & & & $*$ & $*$ & & 6 \\
\hline
\end{tabular}




\begin{tabular}{|c|c|c|c|c|c|c|c|c|c|c|c|}
\hline Guan WJ & 2020 & $*$ & $*$ & $*$ & $*$ & & & $*$ & $*$ & & 6 \\
\hline Guo T & 2020 & $*$ & & $*$ & $*$ & & & $*$ & $*$ & $*$ & 6 \\
\hline $\mathrm{He} \mathrm{R}$ & 2020 & $*$ & $*$ & $*$ & $*$ & & & $*$ & $*$ & & 6 \\
\hline Hong KS & 2020 & $*$ & & $*$ & $*$ & & & $*$ & $*$ & & 5 \\
\hline $\mathrm{Hu} \mathrm{H}$ & 2020 & $*$ & $*$ & $*$ & $*$ & & & $*$ & $*$ & & 6 \\
\hline Huang C & 2020 & $*$ & $*$ & $*$ & $*$ & & & $*$ & $*$ & & 6 \\
\hline Jacobs JP & 2020 & $*$ & $*$ & $*$ & $*$ & & $*$ & $*$ & $*$ & & 7 \\
\hline Javanian M & 2020 & $*$ & $*$ & $*$ & $*$ & & & $*$ & $*$ & & 6 \\
\hline Lei $\mathrm{S}$ & 2020 & $*$ & & $*$ & $*$ & & $*$ & $*$ & $*$ & & 6 \\
\hline $\operatorname{LiX}$ & 2020 & $*$ & $*$ & $*$ & $*$ & & & $*$ & $*$ & & 6 \\
\hline Li YK & 2020 & $*$ & & $*$ & $*$ & & & $*$ & $*$ & & 6 \\
\hline Liang W & 2020 & $*$ & & $*$ & $*$ & $*$ & & $*$ & $*$ & & 6 \\
\hline Liu W & 2020 & $*$ & & $*$ & $*$ & $*$ & $*$ & $*$ & $*$ & & 7 \\
\hline Liu Y & 2020 & $*$ & & $*$ & $*$ & $*$ & & $*$ & $*$ & & 6 \\
\hline Liu Y Du X & 2020 & $*$ & $*$ & $*$ & $*$ & & & $*$ & $*$ & & 6 \\
\hline Liu F & 2020 & $*$ & & $*$ & $*$ & $*$ & & $*$ & $*$ & & 6 \\
\hline Liu J & 2020 & $*$ & $*$ & $*$ & $*$ & & $*$ & $*$ & $*$ & & 7 \\
\hline Lodigiani C & 2020 & $*$ & & $*$ & $*$ & $*$ & & $*$ & $*$ & & 6 \\
\hline Lyu P & 2020 & $*$ & & $*$ & $*$ & $*$ & $*$ & $*$ & $*$ & & 7 \\
\hline Meng $\mathrm{H}$ & 2020 & $*$ & & $*$ & $*$ & & & $*$ & $*$ & $*$ & 6 \\
\hline Meng Y & 2020 & $*$ & & $*$ & $*$ & & & $*$ & $*$ & & 6 \\
\hline Mo P & 2020 & $*$ & $*$ & $*$ & $*$ & & & $*$ & $*$ & & 6 \\
\hline Niu $\mathrm{S}$ & 2020 & $*$ & & $*$ & $*$ & & & $*$ & $*$ & & 6 \\
\hline Onder $\mathrm{G}$ & 2020 & $*$ & & $*$ & $*$ & $*$ & & $*$ & $*$ & & 6 \\
\hline Pan L & 2020 & $*$ & & $*$ & $*$ & & & $*$ & $*$ & & 6 \\
\hline Peng $\mathrm{S}$ & 2020 & $*$ & $*$ & $*$ & $*$ & & $*$ & $*$ & $*$ & & 7 \\
\hline Peng YD & 2020 & $*$ & & $*$ & $*$ & & $*$ & $*$ & $*$ & & 6 \\
\hline Pereira MR & 2020 & $*$ & & $*$ & $*$ & $*$ & & $*$ & $*$ & & 6 \\
\hline $\begin{array}{c}\text { Richardson } \\
\text { S }\end{array}$ & 2020 & $*$ & & $*$ & $*$ & $*$ & & $*$ & $*$ & & 6 \\
\hline Shi S & 2020 & $*$ & & $*$ & $*$ & $*$ & $*$ & $*$ & $*$ & & 7 \\
\hline Shi H & 2020 & $*$ & & $*$ & $*$ & & & $*$ & $*$ & $*$ & 6 \\
\hline Shi Y & 2020 & $*$ & & $*$ & $*$ & $*$ & & $*$ & $*$ & & 6 \\
\hline Sun $\mathrm{H}$ & 2020 & $*$ & $*$ & $*$ & $*$ & $*$ & & $*$ & $*$ & & 7 \\
\hline
\end{tabular}




\begin{tabular}{|c|c|c|c|c|c|c|c|c|c|c|c|}
\hline Sun L & 2020 & $*$ & & $*$ & $*$ & & $*$ & $*$ & $*$ & & 6 \\
\hline $\begin{array}{c}\text { Team } \\
\text { NCPERE }\end{array}$ & 2020 & $*$ & & $*$ & $*$ & & & $*$ & $*$ & $*$ & 6 \\
\hline Tian $\mathrm{S}$ & 2020 & $*$ & & $*$ & $*$ & & & $*$ & $*$ & $*$ & 6 \\
\hline Wan S & 2020 & $*$ & $*$ & $*$ & $*$ & & & $*$ & $*$ & & 6 \\
\hline Wang D & 2020 & $*$ & & $*$ & $*$ & & $*$ & $*$ & $*$ & $*$ & 7 \\
\hline Wang L & 2020 & $*$ & $*$ & $*$ & $*$ & & & $*$ & $*$ & & 6 \\
\hline Wang $\mathrm{R}$ & 2020 & $*$ & & $*$ & $*$ & $*$ & & $*$ & $*$ & $*$ & 7 \\
\hline Wang X & 2020 & $*$ & & $*$ & $*$ & & & $*$ & $*$ & $*$ & 6 \\
\hline Wang $\mathrm{F}$ & 2020 & $*$ & & $*$ & $*$ & & & $*$ & $*$ & $*$ & 6 \\
\hline Wang M & 2020 & $*$ & & $*$ & $*$ & & $*$ & $*$ & $*$ & & 6 \\
\hline $\mathrm{Wu} \mathrm{C}$ & 2020 & $*$ & & $*$ & $*$ & $*$ & $*$ & * & $*$ & $*$ & 8 \\
\hline $\mathrm{Wu} \mathrm{J}$ & 2020 & $*$ & $*$ & $*$ & $*$ & & & $*$ & $*$ & & 6 \\
\hline Xie H & 2020 & $*$ & & $*$ & $*$ & & & $*$ & $*$ & $*$ & 6 \\
\hline Xie J & 2020 & $*$ & & $*$ & $*$ & & & $*$ & $*$ & & 6 \\
\hline Xiong F & 2020 & $*$ & & $*$ & $*$ & $*$ & & $*$ & $*$ & & 6 \\
\hline Yan $Y$ & 2020 & $*$ & $*$ & $*$ & $*$ & & & $*$ & $*$ & & 7 \\
\hline Yang X & 2020 & $*$ & & $*$ & $*$ & & $*$ & $*$ & $*$ & & 6 \\
\hline Yang Fa & 2020 & $*$ & & $*$ & $*$ & & & $*$ & $*$ & $*$ & 6 \\
\hline Yang $\mathrm{Fb}$ & 2020 & $*$ & $*$ & $*$ & $*$ & & & $*$ & $*$ & $*$ & 7 \\
\hline Yang Y & 2020 & $*$ & $*$ & $*$ & $*$ & & & $*$ & $*$ & & 6 \\
\hline Yao Q & 2020 & $*$ & $*$ & $*$ & $*$ & & & $*$ & $*$ & & 6 \\
\hline $\mathrm{YuX}$ & 2020 & $*$ & & $*$ & $*$ & $*$ & & $*$ & $*$ & & 6 \\
\hline Yuan M & 2020 & $*$ & & $*$ & $*$ & $*$ & & $*$ & $*$ & & 6 \\
\hline Zhang JJ & 2020 & $*$ & $*$ & $*$ & $*$ & & & $*$ & $*$ & & 6 \\
\hline Zhang J & 2020 & $*$ & & $*$ & $*$ & & & $*$ & $*$ & $*$ & 6 \\
\hline Zhao XY & 2020 & $*$ & & $*$ & $*$ & & & $*$ & $*$ & & 5 \\
\hline Zheng F & 2020 & $*$ & $*$ & $*$ & $*$ & $*$ & $*$ & $*$ & $*$ & & 8 \\
\hline Zheng S & 2020 & $*$ & & $*$ & $*$ & $*$ & & $*$ & $*$ & & 6 \\
\hline Zhou F & 2020 & $*$ & $*$ & $*$ & $*$ & & & $*$ & $*$ & & 6 \\
\hline Zhou Y & 2020 & $*$ & $*$ & $*$ & $*$ & & & $*$ & $*$ & & 6 \\
\hline
\end{tabular}

NOS=Newcastle Otawa Scale; in this scale score ranges between $0-9$ where " $0-3$ " indicates low quality, "4-5" indicates moderate quality and score of $\geq 6$ indicates high quality study 
medRxiv preprint doi: https://doi.org/10.1101/2020.05.23.20110965; this version posted May 26, 2020. The copyright holder for this preprint (which was not certified by peer review) is the author/funder, who has granted medRxiv a license to display the preprint in perpetuity.

\section{It is made available under a CC-BY-ND 4.0 International license .}

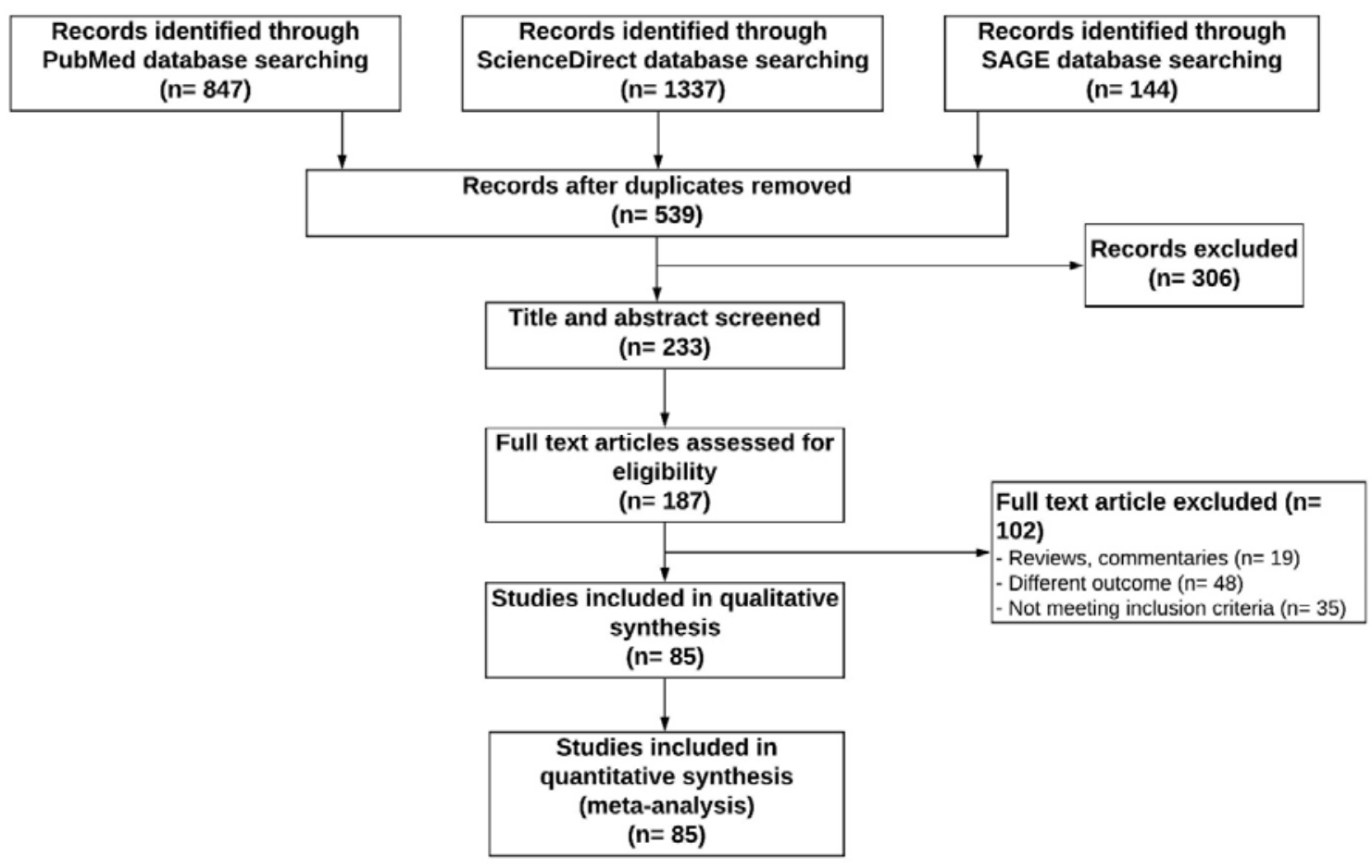

Figure 1.Flow diagram for selection of studies for inclusion in this meta-analysis 
medRxiv preprint doi: https://doi.org/10.1101/2020.05.23.20110965; this version posted May 26, 2020. The copyright holder for this preprint (which was not certified by peer review) is the author/funder, who has granted medRxiv a license to display the preprint in perpetuity.

It is made available under a CC-BY-ND 4.0 International license .

Male Female Odds Ratio

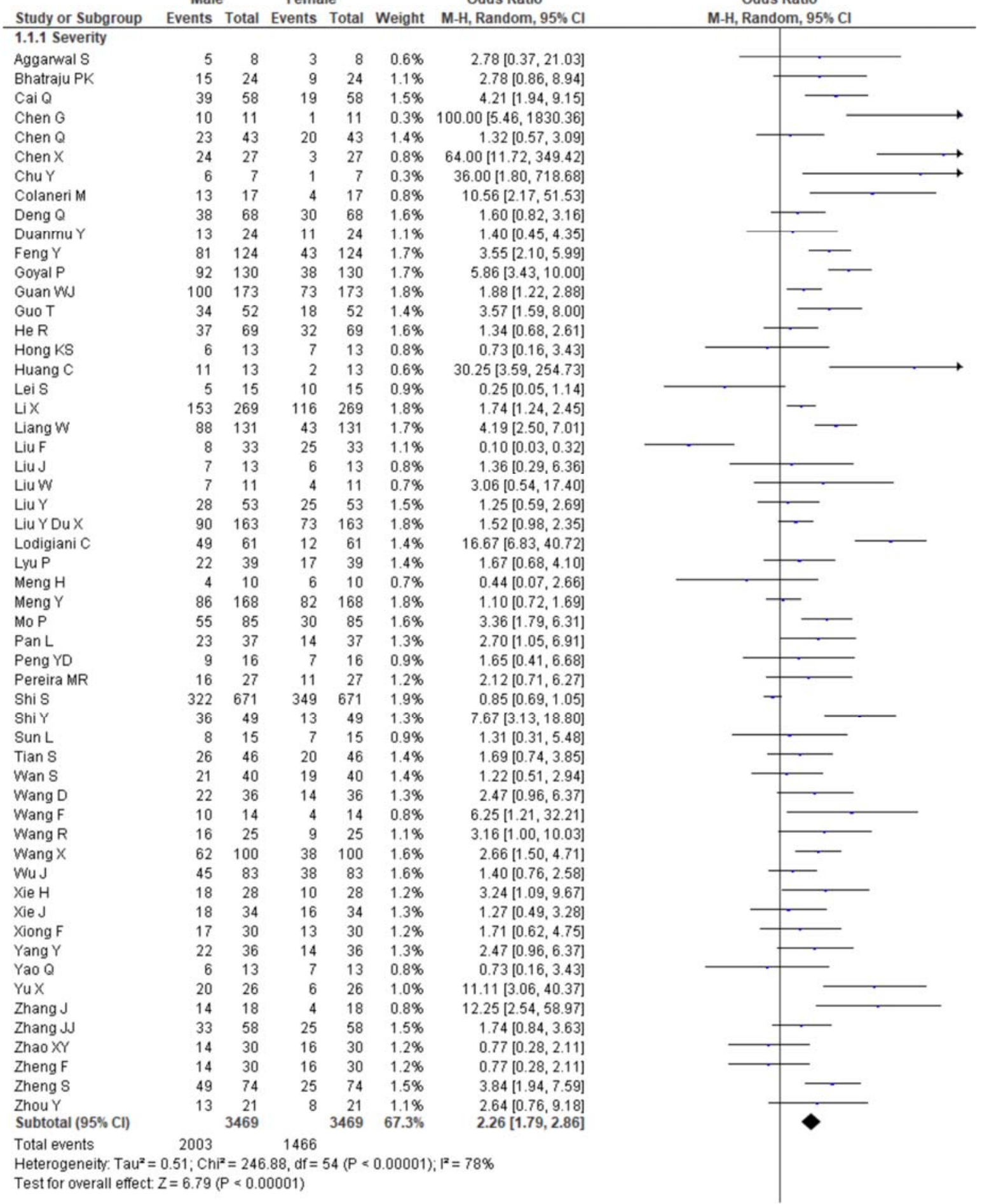


medRxiv preprint doi: https://doi.org/10.1101/2020.05.23.20110965; this version posted May 26, 2020. The copyright holder for this preprint (which was not certified by peer review) is the author/funder, who has granted medRxiv a license to display the preprint in perpetuity.

It is made available under a CC-BY-ND 4.0 International license .

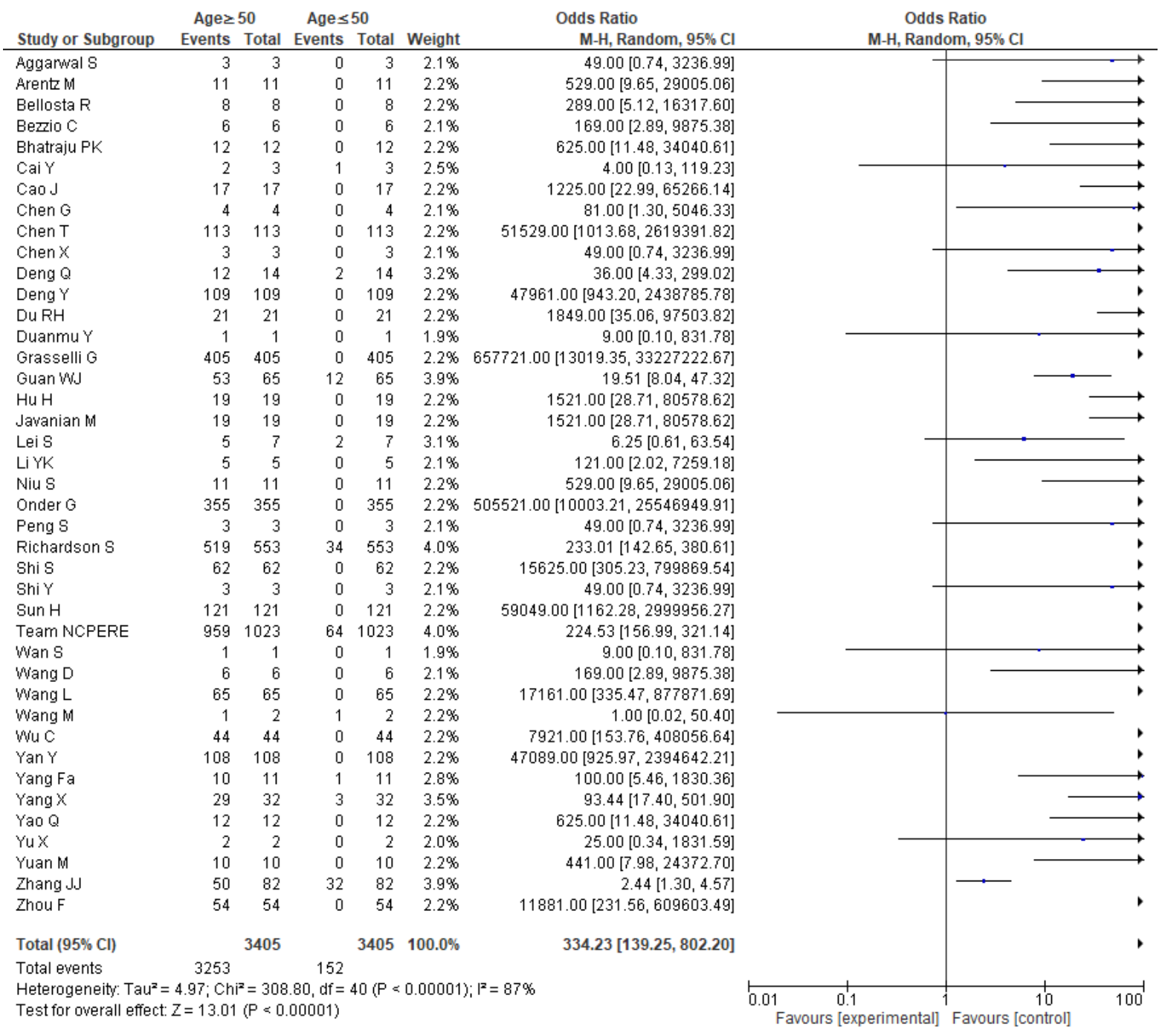

Figure 3. Pooled effects of age on COVID-19-linked death (age $\geq 50$ Vs. age $<50$ years) 
medRxiv preprint doi: https://doi.org/10.1101/2020.05.23.20110965; this version posted May 26, 2020. The copyright holder for this preprint (which was not certified by peer review) is the author/funder, who has granted medRxiv a license to display the preprint in perpetuity.

It is made available under a CC-BY-ND 4.0 International license .

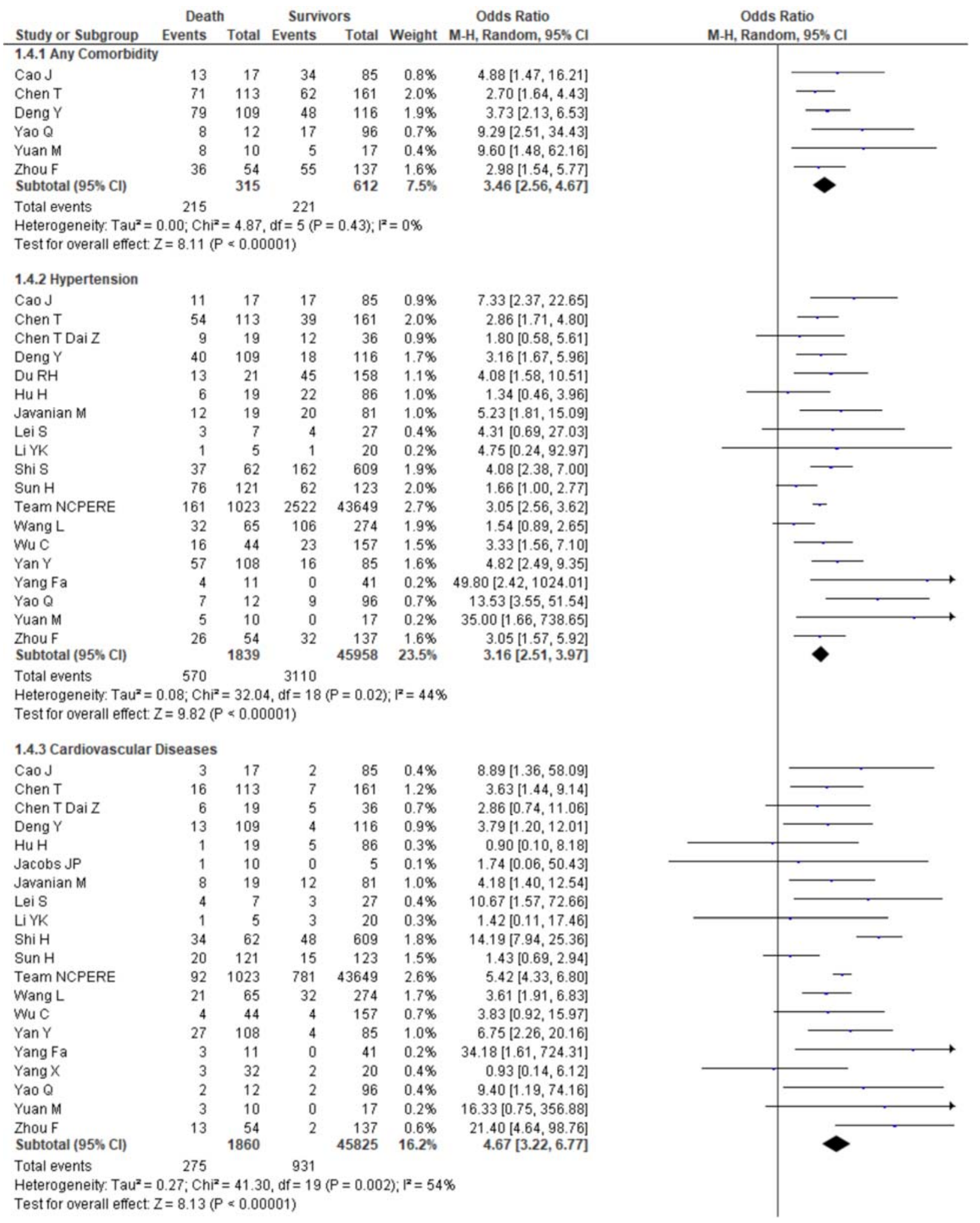


medRxiv preprint doi: https://doi.org/10.1101/2020.05.23.20110965; this version posted May 26, 2020. The copyright holder for this preprint (which was not certified by peer review) is the author/funder, who has granted medRxiv a license to display the preprint in perpetuity.

It is made available under a CC-BY-ND 4.0 International license.

1.4.4 Diabetes

Cao J

Chen T

Chen T Dai Z

Deng $Y$

Du RH

$\mathrm{HuH}$

Jacobs JP

Javanian M

Lei S

Li YK

Shi S

Sun $\mathrm{H}$

Team NCPERE

Wang L

Wu C

Yan $Y$

Yang $\mathrm{Fa}$

Yang $X$

Yao Q

Yuan M

Zhou $F$

Subtotal $(95 \% \mathrm{Cl})$

Total events

Heterogeneity. $\operatorname{Tau}^{2}=0.17 ; \mathrm{Chi}^{2}=38.84, \mathrm{df}=20(\mathrm{P}=0.007) ; \mathrm{I}^{2}=49 \%$

Test for overall effect $Z=5.91(P \propto 0.00001)$

1.4.5 Cerebrovascular Disease

$\begin{array}{lrrrrr}\text { Cao J } & 3 & 17 & 3 & 85 & 0.5 \% \\ \text { Chen T } & 4 & 113 & 0 & 161 & 0.2 \% \\ \text { Chen T Dai Z } & 3 & 19 & 5 & 36 & 0.6 \% \\ \text { Du RH } & 12 & 21 & 17 & 158 & 1.1 \% \\ \text { Hu H } & 3 & 19 & 1 & 86 & 0.3 \% \\ \text { Javanian M } & 2 & 19 & 1 & 81 & 0.3 \% \\ \text { Lei S } & 1 & 7 & 6 & 27 & 0.3 \% \\ \text { Shi S } & 8 & 62 & 14 & 609 & 1.2 \% \\ \text { Wang L } & 10 & 65 & 11 & 274 & 1.2 \% \\ \text { Yan Y } & 8 & 108 & 0 & 85 & 0.2 \% \\ \text { Yang Fa } & 3 & 11 & 0 & 41 & 0.2 \% \\ \text { Yang X } & 7 & 32 & 0 & 20 & 0.2 \% \\ \text { Yuan M } & 1 & 10 & 0 & 17 & 0.2 \% \\ \text { Subtotal }(95 \% \mathrm{CI}) & & 503 & & 1680 & 6.3 \% \\ \text { Total events } & 65 & & 58 & & \end{array}$

Heterogeneity. Tau $^{2}=0.06 ; \mathrm{Chi}^{2}=13.07, \mathrm{df}=12(\mathrm{P}=0.36) ; \mathrm{I}^{2}=8 \%$

Test for overall effect: $Z=7.29$ ( $P<0.00001)$

1.4.6 Respiratory Disease

\begin{tabular}{|c|c|c|c|c|c|}
\hline Cao J & 4 & 17 & 6 & 85 & $0.7 \%$ \\
\hline Chen $\mathrm{T}$ & 11 & 113 & 7 & 161 & $1.1 \%$ \\
\hline Chen T Dai Z & 1 & 19 & 6 & 36 & $0.3 \%$ \\
\hline Deng $Y$ & 22 & 109 & 3 & 116 & $0.8 \%$ \\
\hline $\mathrm{HuH}$ & 5 & 19 & 7 & 86 & $0.8 \%$ \\
\hline Jacobs JP & 0 & 10 & 1 & 5 & $0.1 \%$ \\
\hline Javanian M & 5 & 19 & 7 & 81 & $0.8 \%$ \\
\hline Lei S & 1 & 7 & 6 & 27 & $0.3 \%$ \\
\hline LIYK & 3 & 5 & 2 & 20 & $0.3 \%$ \\
\hline Shi S & 2 & 62 & 21 & 609 & $0.6 \%$ \\
\hline Sun $\mathrm{H}$ & 20 & 121 & 4 & 123 & $0.9 \%$ \\
\hline Team NCPERE & 32 & 1023 & 479 & 43649 & $2.3 \%$ \\
\hline Wang L & 1 & 65 & 10 & 274 & $0.4 \%$ \\
\hline Yan $Y$ & 11 & 108 & 3 & 85 & $0.7 \%$ \\
\hline Yang $\mathrm{Fa}$ & 1 & 11 & 0 & 41 & $0.2 \%$ \\
\hline Yang $X$ & 2 & 32 & 2 & 20 & $0.4 \%$ \\
\hline Yao Q & 0 & 12 & 3 & 96 & $0.2 \%$ \\
\hline $\begin{array}{l}\text { Zhou F } \\
\text { Subtotal }(95 \% \mathrm{Cl})\end{array}$ & 4 & $\begin{array}{r}54 \\
1806\end{array}$ & 2 & $\begin{array}{r}137 \\
45651\end{array}$ & $\begin{array}{r}0.5 \% \\
11.3 \%\end{array}$ \\
\hline Total events & 125 & & 569 & & \\
\hline
\end{tabular}

Heterogeneity: $\mathrm{Tau}^{2}=0.24 ; \mathrm{Chi}^{2}=26.54, \mathrm{df}=17(\mathrm{P}=0.07) ; \mathrm{I}^{2}=36 \%$

Test for overall effect: $Z=4.56$ ( $P<0.00001)$
$8.73[2.28,33.46]$

$1.62[0.86,3.04]$

$1.48[0.40,5.50]$

$2.20[0.93,5.16]$

$1.94[0.69,5.45]$

$0.47[0.02,9.10]$

$1.50[0.17,13.23]$

$2.22[0.81,6.11]$

$0.58[0.06,5.84]$

$13.67[0.48,393.18]$

$2.50[1.36,4.58]$

$1.18[0.64,2.20]$

$3.54[2.79,4.48]$

$1.09[0.53,2.26]$

$4.42[1.77,11.07]$

$4.77[2.16,10.57]$

$34.18[1.61,724.31]$

$2.52[0.47,13.58]$

$2.09[0.21,20.42]$

$50.56[2.38,1075.32]$

$2.85[1.35,6.05]$

2.45 [1.82, 3.30]

$5.86[1.07,31.99]$

$13.27[0.71,249.04]$

$1.16[0.25,5.50]$

$11.06[4.07,30.06]$

$15.94[1.56,163.04]$

$9.41[0.81,109.82]$

$0.58[0.06,5.84]$

$6.30[2.53,15.68]$

$4.35[1.76,10.74]$

$14.46[0.82,254.24]$

$34.18[1.61,724.31]$

$12.06[0.65,223.84]$

$5.53[0.20,149.33]$

$5.84[3.63,9.39]$

$4.05[1.00,16.34]$

$2.37[0.89,6.32]$

$0.28[0.03,2.50]$

$9.52[2.76,32.86]$

$4.03[1.12,14.51]$

$0.14[0.00,4.22]$

$3.78[1.05,13.61]$

$0.58[0.06,5.84]$

$13.50[1.34,135.98]$

$0.93[0.21,4.08]$

$5.89[1.95,17.80]$

$2.91[2.02,4.19]$

$0.41[0.05,3.28]$

$3.10[0.84,11.49]$

$11.86[0.45,312.43]$

$0.60[0.08,4.64]$

$1.07[0.05,21.93]$

$5.40[0.96,30.40]$

$2.68[1.75,4.09]$
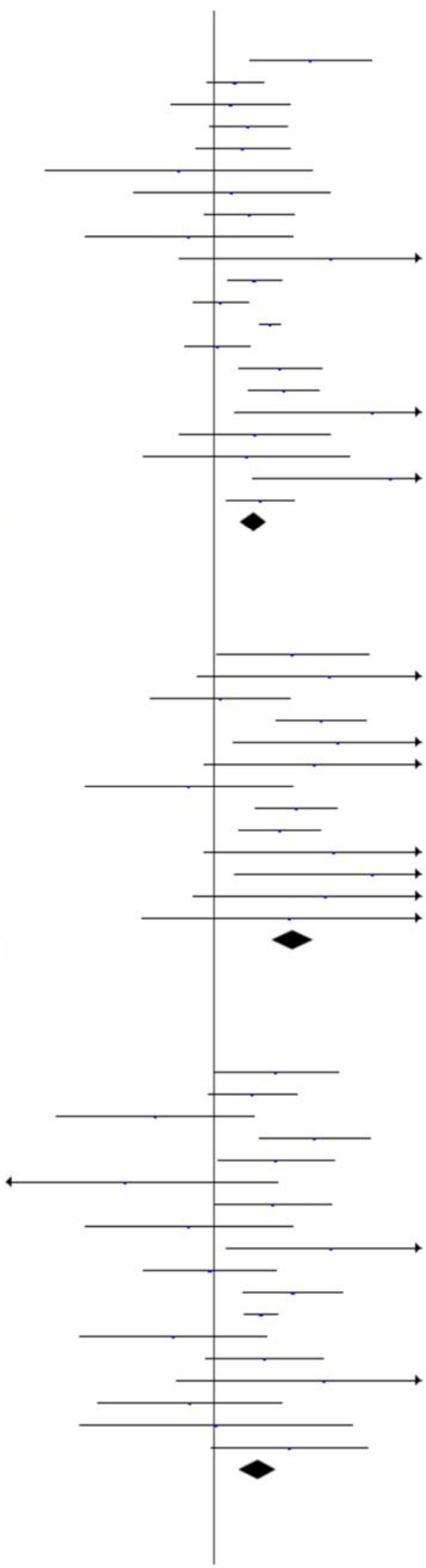
medRxiv preprint doi: https://doi.org/10.1101/2020.05.23.20110965; this version posted May 26, 2020. The copyright holder for this preprint (which was not certified by peer review) is the author/funder, who has granted medRxiv a license to display the preprint in perpetuity.

It is made available under a CC-BY-ND 4.0 International license .

1.4.7 Kidney disease

Cao J

Chen T

Chen T Dai Z

Javanian M

Shis

Wang L

Yan $Y$

Yang Fa

Zhou $F$

Subtotal $(95 \% \mathrm{CI})$

Total events

Heterogeneity: Tau $^{2}=0.00 ; \mathrm{Chi}^{2}=7.03, \mathrm{df}=8(P=0.53) ; \mathrm{I}^{2}=0 \%$

Test for overall effect $Z=6.51(P<0.00001)$

1.4.8 Liver Disease

Cao J

Chen T

Chen T Dai Z

Du RH

Javanian M

Wang L

Yan $Y$

Yao Q

Subtotal $(95 \% \mathrm{CI})$

Total events

Heterogeneity, $\mathrm{Tau}^{2}=0.00 ; \mathrm{Chi}^{2}=4.77, \mathrm{df}=7(\mathrm{P}=0.69) ; \mathrm{I}^{2}=0 \%$

Test for overall effect: $Z=2.67(P=0.008)$

1.4.9 Malignancy

Cao J

Chen T

Chen T Dai Z

Deng $Y$

DuRH

$\mathrm{HuH}$

Jacobs JP

Javanian $M$

Lei S

Shi S

Team NCPERE

Wang L

Yang $\mathrm{Fa}$

Yang $X$

Yao Q

Yuan M

Zhou $F$

Subtotal $(95 \% \mathrm{Cl})$

Total events

Heterogeneity, $\mathrm{Tau}^{2}=0.00 ; \mathrm{Chi}^{2}=14.27 \mathrm{df}=15(\mathrm{P}=0.51) ; \mathrm{I}^{2}=0 \%$

Test for overall effect: $Z=3.52(P=0.0004)$

1.4.10 GI disorders

Chen $\mathrm{T}$

Du RH

Yuan M

Subtotal $(95 \% \mathrm{Cl})$

Total events

$\begin{array}{rrrrr}1 & 17 & 3 & 85 & 0.3 \%\end{array}$

$161 \quad 0.5 \%$

$36 \quad 0.3 \%$

$116 \quad 0.5 \%$

$158 \quad 0.3 \%$

$86 \quad 0.3 \%$

$5 \quad 0.2 \%$

$81 \quad 0.3 \%$

$\begin{array}{ll}81 & 0.3 \% \\ 27 & 0.4 \%\end{array}$

$609 \quad 0.9 \%$

$43649 \quad 1.3 \%$

$2740.8 \%$

$20 \quad 0.2 \%$

$96 \quad 0.2 \%$

$17 \quad 0.2 \%$

$137 \quad 0.2 \%$

$45598 \quad 6.9 \%$

202

Heterogeneity. Tau $^{2}=0.00 ; \mathrm{Chi}^{2}=0.95, \mathrm{df}=2(P=0.62) ; \mathrm{I}^{2}=0 \%$

Test for overall effect $Z=0.69(P=0.49)$

Total $(95 \% \mathrm{CI})$

$234128100.0 \%$

Total events 1648 6484

Heterogeneity. Tau $^{2}=0.16 ; \mathrm{Chi}^{2}=234.17, \mathrm{df}=132(\mathrm{P}<0.00001) ; \mathrm{I}^{2}=44 \%$

Test for overall effect: $Z=17.73$ ( $P<0.00001)$

Test for subqroup differences: $\mathrm{Chi}^{2}=24.30, \mathrm{df}=9(\mathrm{P}=0.004), \mathrm{I}^{2}=63.0 \%$
$18.00[1.75,185.53]$

$13.27[0.71,249.04]$

$4.12[0.35,48.65]$

$3.78[1.05,13.61]$

$8.89[3.99,19.84]$

$1.93[0.58,6.48]$

$2.40[0.25,23.49]$

$11.86[0.45,312.43]$

$13.10[0.62,277.33]$

$5.62[3.34,9.46]$

$2.59[0.22,30.34]$

$1.20[0.36,4.02]$

$1.94[0.11,32.93]$

$8.21[1.09,61.71]$

$9.41[0.81,109.82]$

$4.27[0.26,69.11]$

$2.39[0.10,59.31]$

$8.64[0.50,148.00]$

$2.81[1.31,6.01]$

$1.71[0.17,17.48]$

$3.68[0.70,19.32]$

$0.44[0.05,4.29]$

$3.32[0.66,16.82]$

$2.58[0.26,26.04]$

$0.90[0.10,8.18]$

$0.44[0.02,9.03]$

$15.00[1.47,153.55]$

$10.67[1.57,72.66]$

$2.14[0.70,6.51]$

$2.54[1.11,5.81]$

$1.06[0.29,3.86]$

Not estimable

$0.61[0.04,10.39]$

$8.64[0.50,148.00]$

$0.52[0.02,14.10]$

$0.50[0.02,10.53]$

$2.16[1.41,3.33]$

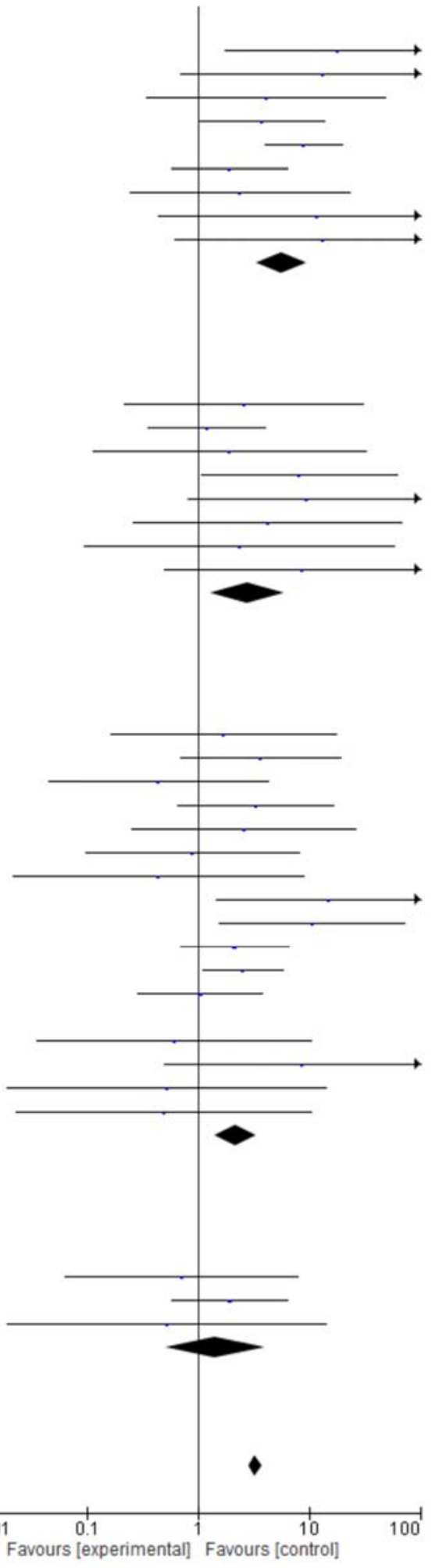

Figure 4. Pooled effects of comorbidities on the death linked with COVID-19 
medRxiv preprint doi: https://doi.org/10.1101/2020.05.23.20110965; this version posted May 26, 2020. The copyright holder for this preprint (which was not certified by peer review) is the author/funder, who has granted medRxiv a license to display the preprint in perpetuity.

It is made available under a CC-BY-ND 4.0 International license.

\begin{tabular}{|c|c|c|c|c|c|c|c|}
\hline \multirow[b]{2}{*}{ Study or Subgroup } & \multicolumn{2}{|c|}{ Death } & \multicolumn{2}{|c|}{ Survivors } & \multirow[b]{2}{*}{ Weight } & Odds Ratio & \multirow{2}{*}{$\begin{array}{c}\text { Odds Ratio } \\
\text { M-H, Random, } 95 \% \mathrm{Cl}\end{array}$} \\
\hline & Events & Total & Events & Total & & M-H, Random, $95 \% \mathrm{Cl}$ & \\
\hline \multicolumn{8}{|l|}{ 1.5.1 Fever } \\
\hline Cao J & 12 & 17 & 61 & 85 & $1.1 \%$ & $0.94[0.30,2.97]$ & \\
\hline Chen $\mathrm{T}$ & 104 & 113 & 145 & 161 & $1.4 \%$ & $1.28[0.54,3.00]$ & \\
\hline Chen T Dai Z & 17 & 19 & 35 & 36 & $0.4 \%$ & $0.24[0.02,2.87]$ & \\
\hline Deng $Y$ & 95 & 109 & 94 & 116 & $1.6 \%$ & $1.59[0.77,3.29]$ & \\
\hline Du RH & 21 & 21 & 156 & 158 & $0.2 \%$ & $0.69[0.03,14.79]$ & \\
\hline Javanian $\mathrm{M}$ & 15 & 19 & 62 & 81 & $1.0 \%$ & $1.15[0.34,3.88]$ & \\
\hline LiYK & 5 & 5 & 19 & 20 & $0.2 \%$ & $0.85[0.03,23.82]$ & \\
\hline Peng $\mathrm{S}$ & 3 & 3 & 8 & 8 & & Not estimable & \\
\hline Sun $\mathrm{H}$ & 107 & 121 & 104 & 123 & $1.6 \%$ & $1.40[0.67,2.93]$ & \\
\hline Wang L & 56 & 65 & 255 & 274 & $1.5 \%$ & $0.46[0.20,1.08]$ & \\
\hline Wu C & 39 & 44 & 149 & 157 & $1.1 \%$ & $0.42[0.13,1.35]$ & \\
\hline Yao Q & 8 & 12 & 70 & 96 & $1.0 \%$ & $0.74[0.21,2.68]$ & \\
\hline Yuan M & 6 & 10 & 15 & 17 & $0.5 \%$ & $0.20[0.03,1.40]$ & \\
\hline Zhou F & 51 & 54 & 129 & 137 & $0.9 \%$ & $1.05[0.27,4.13]$ & \\
\hline Subtotal $(95 \% \mathrm{Cl})$ & & 612 & & 1469 & $12.5 \%$ & $0.93[0.68,1.27]$ & \\
\hline Total events & 539 & & 1302 & & & & \\
\hline \multirow{2}{*}{\multicolumn{8}{|c|}{$\begin{array}{l}\text { Heterogeneity. } \text { Tau }^{2}=0.00 ; \mathrm{Ch}^{2}=12.01, \mathrm{df}=12(P=0.45) ; \mathrm{I}^{2}=0 \% \\
\text { Test for overall effect } Z=0.44(P=0.66)\end{array}$}} \\
\hline & & & & & & & \\
\hline \multicolumn{8}{|l|}{ 1.5.2 Cough } \\
\hline $\mathrm{CaOJ}$ & 8 & 17 & 42 & 85 & $1.2 \%$ & $0.91[0.32,2.58]$ & \\
\hline Chen $\mathrm{T}$ & 79 & 113 & 106 & 161 & $1.9 \%$ & $1.21[0.72,2.02]$ & \\
\hline Chen T Dai Z & 15 & 19 & 23 & 36 & $0.9 \%$ & $2.12[0.58,7.74]$ & \\
\hline Deng $Y$ & 47 & 109 & 38 & 116 & $1.9 \%$ & $1.56[0.90,2.68]$ & \\
\hline Du RH & 14 & 21 & 132 & 158 & $1.3 \%$ & $0.39[0.14,1.07]$ & \\
\hline Javanian M & 16 & 19 & 66 & 81 & $0.9 \%$ & $1.21[0.31,4.70]$ & \\
\hline LiYK & 4 & 5 & 13 & 20 & $0.4 \%$ & $2.15[0.20,23.18]$ & \\
\hline Peng $\mathrm{s}$ & 3 & 3 & 6 & 8 & $0.2 \%$ & $2.69[0.10,73.20]$ & \\
\hline Sun $\mathrm{H}$ & 88 & 121 & 91 & 123 & $1.9 \%$ & $0.94[0.53,1.65]$ & - \\
\hline Wang L & 30 & 65 & 149 & 274 & $1.9 \%$ & $0.72[0.42,1.24]$ & - \\
\hline Wu C & 33 & 44 & 131 & 157 & $1.5 \%$ & $0.60[0.27,1.33]$ & - \\
\hline Yao Q & 10 & 12 & 74 & 96 & $0.7 \%$ & $1.49[0.30,7.30]$ & \\
\hline Yuan $\mathrm{M}$ & 5 & 10 & 11 & 17 & $0.7 \%$ & $0.55[0.11,2.67]$ & \\
\hline Zhou F & 39 & 54 & 112 & 137 & $1.6 \%$ & $0.58[0.28,1.21]$ & \\
\hline Subtotal $(95 \% \mathrm{CI})$ & & 612 & & 1469 & $17.1 \%$ & $0.94[0.74,1.18]$ & \\
\hline Total events & 391 & & 994 & & & & \\
\hline \multicolumn{8}{|c|}{$\begin{array}{l}\text { Heterogeneity. } \text { Tau }^{2}=0.02 ; \mathrm{Chi}^{2}=14.24, \mathrm{df}=13(P=0.36) ; \mathrm{l}^{2}=9 \% \\
\text { Test for overall effect } Z=0.55(P=0.58)\end{array}$} \\
\hline
\end{tabular}


medRxiv preprint doi: https://doi.org/10.1101/2020.05.23.20110965; this version posted May 26, 2020. The copyright holder for this preprint (which was not certified by peer review) is the author/funder, who has granted medRxiv a license to display the preprint in perpetuity.

It is made available under a CC-BY-ND 4.0 International license.

\begin{tabular}{|c|c|c|c|c|c|c|}
\hline \multicolumn{7}{|l|}{ 1.5.3 Fatigue } \\
\hline Cao J & 9 & 17 & 47 & 85 & $1.2 \%$ & $0.91[0.32,2.58$ \\
\hline Chen T & 64 & 113 & 73 & 161 & $2.0 \%$ & $1.57[0.97,2.56]$ \\
\hline Chen T Dai Z & 2 & 19 & 3 & 36 & $0.6 \%$ & $1.29[0.20,8.50]$ \\
\hline Deng $Y$ & 30 & 109 & 27 & 116 & $1.8 \%$ & $1.25[0.69,2.28$ \\
\hline Du RH & 13 & 21 & 58 & 158 & $1.3 \%$ & $2.80[1.10,7.16$ \\
\hline Javanian M & 15 & 19 & 62 & 81 & $1.0 \%$ & $1.15[0.34,3.88]$ \\
\hline LIYK & 3 & 5 & 14 & 20 & $0.5 \%$ & $0.64[0.08,4.89]$ \\
\hline Peng S & 3 & 3 & 7 & 8 & $0.2 \%$ & $1.40[0.04,43.79$ \\
\hline Wang L & 26 & 65 & 109 & 274 & $1.9 \%$ & $1.01[0.58,1.75$ \\
\hline wuc & 15 & 44 & 50 & 157 & $1.6 \%$ & $1.11[0.55,2.25]$ \\
\hline Yao Q & 4 & 12 & 24 & 96 & $1.0 \%$ & $1.50[0.41,5.43$ \\
\hline $\begin{array}{l}\text { Zhou F } \\
\text { Subtotal }(95 \% \mathrm{Cl})\end{array}$ & 15 & $\begin{array}{r}54 \\
481\end{array}$ & 29 & $\begin{array}{r}137 \\
1329\end{array}$ & $\begin{array}{r}1.6 \% \\
14.7 \%\end{array}$ & $\begin{array}{l}1.43[0.70,2.95 \\
1.31[1.04,1.66\end{array}$ \\
\hline Total events & 199 & & 503 & & & \\
\hline \multicolumn{7}{|c|}{$\begin{array}{l}\text { Heterogeneity: } \text { Tau }^{2}=0.00 ; C h i^{2}=5.26, d f=11(P=0.92) ; I^{2}=0 \% \\
\text { Test for overall effect } Z=2.25(P=0.02)\end{array}$} \\
\hline \multicolumn{7}{|l|}{ 1.5.4 Myalgia } \\
\hline $\mathrm{CaOJ}$ & 5 & 17 & 30 & 85 & $1.1 \%$ & $0.76[0.25,2.37$ \\
\hline Chen $T$ & 21 & 113 & 39 & 161 & $1.8 \%$ & $0.71[0.39,1.30]$ \\
\hline Chen TDai Z & 2 & 19 & 9 & 36 & $0.7 \%$ & $0.35[0.07,1.83$ \\
\hline Du RH & 7 & 21 & 27 & 158 & $1.3 \%$ & $2.43[0.89,6.58$ \\
\hline Javanian M & 9 & 19 & 41 & 81 & $1.3 \%$ & $0.88[0.32,2.39]$ \\
\hline Wang L & 1 & 65 & 15 & 274 & $0.5 \%$ & $0.27[0.03,2.08]$ \\
\hline Yuan $\mathrm{M}$ & 1 & 10 & 2 & 17 & $0.3 \%$ & $0.83[0.07,10.55$ \\
\hline Zhou F & 8 & 54 & 21 & 137 & $1.4 \%$ & $0.96[0.40,2.32$ \\
\hline Subtotal $(95 \% \mathrm{Cl})$ & & 318 & & 949 & $8.4 \%$ & $0.86[0.60,1.24]$ \\
\hline Total events & 54 & & 184 & & & \\
\hline \multirow{2}{*}{\multicolumn{7}{|c|}{$\begin{array}{l}\text { Heterogeneity: } \text { Tau }^{2}=0.00 ; \mathrm{Chi}^{2}=7.06, d f=7(P=0.42) ; 1^{2}=1 \% \\
\text { Test for overall effect: } Z=0.82(P=0.41)\end{array}$}} \\
\hline & & & & & & \\
\hline \multicolumn{7}{|l|}{ 1.5.5 Dyspnea } \\
\hline Chen $T$ & 70 & 113 & 50 & 161 & $1.9 \%$ & $3.61[2.18,5.99]$ \\
\hline Chen T Dai Z & 1 & 19 & 0 & 36 & $0.2 \%$ & $5.92[0.23,152.52$ \\
\hline Deng $Y$ & 77 & 109 & 22 & 116 & $1.8 \%$ & $10.28[5.53,19.13$ \\
\hline Du RH & 18 & 21 & 71 & 158 & $1.0 \%$ & $7.35[2.08,25.97]$ \\
\hline Javanian M & 16 & 19 & 66 & 81 & $0.9 \%$ & $1.21[0.31,4.70$ \\
\hline LiYK & 4 & 5 & 16 & 20 & $0.4 \%$ & $1.00[0.09,11.59$ \\
\hline Peng S & 3 & 3 & 8 & 8 & & Not estimable \\
\hline Wang L & 38 & 65 & 100 & 274 & $1.9 \%$ & $2.45[1.41,4.25$ \\
\hline WuC & 29 & 44 & 51 & 157 & $1.6 \%$ & $4.02[1.98,8.15]$ \\
\hline Yao Q & 6 & 12 & 9 & 96 & $0.9 \%$ & $9.67[2.57,36.31]$ \\
\hline Yuan M & 10 & 10 & 1 & 17 & $0.2 \%$ & $231.00[8.58,6218.11]$ \\
\hline Subtotal $(95 \% \mathrm{Cl})$ & & 420 & & 1124 & $10.9 \%$ & $4.57[2.69,7.78]$ \\
\hline Total events & 272 & & 394 & & & \\
\hline \multicolumn{7}{|c|}{ Heterogeneity: $\operatorname{Tau}^{2}=0.36 ; \mathrm{Chi}^{2}=24.61, \mathrm{df}=9(\mathrm{P}=0.003) ; \mathrm{I}^{2}=63 \%$} \\
\hline
\end{tabular}

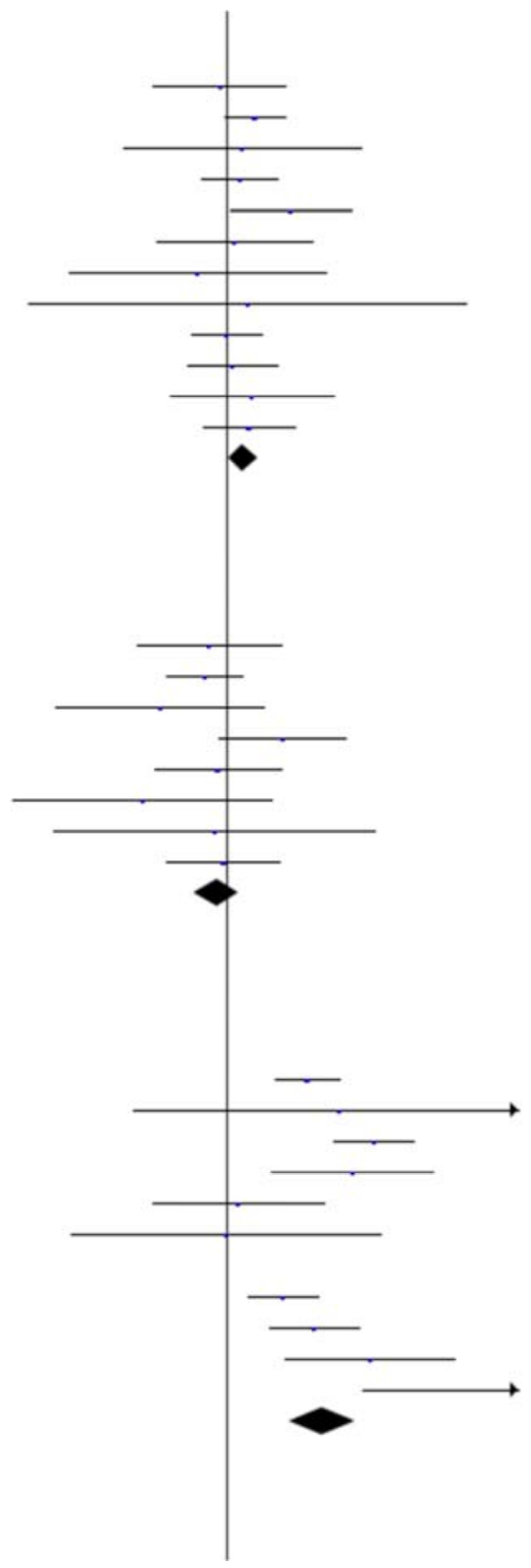


medRxiv preprint doi: https://doi.org/10.1101/2020.05.23.20110965; this version posted May 26, 2020. The copyright holder for this preprint (which was not certified by peer review) is the author/funder, who has granted medRxiv a license to display the preprint in perpetuity.

It is made available under a CC-BY-ND 4.0 International license.

1.5.6 Sputum production

\begin{tabular}{lrrrrr} 
Chen T & 35 & 113 & 48 & 161 & $1.9 \%$ \\
Du RH & 12 & 21 & 43 & 158 & $1.3 \%$ \\
Javanian M & 7 & 19 & 38 & 81 & $1.2 \%$ \\
Peng S & 2 & 3 & 2 & 8 & $0.3 \%$ \\
Zhou F & 14 & 54 & 30 & 137 & $1.6 \%$ \\
Subtotal $(95 \% \mathrm{CI})$ & \multicolumn{7}{c}{$\mathbf{2 1 0}$} & & 545 & $6.4 \%$ \\
Total events & 70 & & \\
Heterogeneity: Tau & $=0.19 ; \mathrm{Ch}^{2}=7.85, \mathrm{df}=4(\mathrm{P}=0.10) ; \mathrm{I}^{2}=49 \%$ \\
Test for overall effect: $\mathrm{Z}=1.11(\mathrm{P}=0.27)$
\end{tabular}

1.5.7 Diarrhoea

\begin{tabular}{|c|c|c|c|c|c|}
\hline Cao J & 3 & 17 & 8 & 85 & $0.8 \%$ \\
\hline Chen T & 27 & 113 & 50 & 161 & $1.9 \%$ \\
\hline Chen T Dai Z & 1 & 19 & 2 & 36 & $0.4 \%$ \\
\hline Deng $Y$ & 19 & 109 & 14 & 116 & $1.6 \%$ \\
\hline Javanian M & 2 & 19 & 12 & 81 & $0.7 \%$ \\
\hline LiYK & 1 & 5 & 4 & 20 & $0.4 \%$ \\
\hline Peng $S$ & 2 & 3 & 1 & 8 & $0.2 \%$ \\
\hline Sun $\mathrm{H}$ & 36 & 121 & 36 & 123 & $1.9 \%$ \\
\hline Wang L & 8 & 65 & 35 & 274 & $1.5 \%$ \\
\hline Yao Q & 1 & 12 & 7 & 96 & $0.4 \%$ \\
\hline $\begin{array}{l}\text { Zhou F } \\
\text { Subtotal }(95 \% \mathrm{Cl})\end{array}$ & 2 & $\begin{array}{r}54 \\
537\end{array}$ & 7 & $\begin{array}{r}137 \\
1137\end{array}$ & $\begin{array}{r}0.7 \% \\
10.5 \%\end{array}$ \\
\hline Total events & 102 & & 176 & & \\
\hline
\end{tabular}

1.5.8 Headache

Chen $T$

Chen T Dai Z

Deng $Y$

DuRH

Javanian M

Peng S

Wang $L$

Yao Q

Subtotal $(95 \% \mathrm{CI})$

Total events

\begin{tabular}{rr}
11 & 113 \\
0 & 19 \\
6 & 109 \\
5 & 21 \\
9 & 19 \\
3 & 3 \\
0 & 65 \\
0 & 12 \\
\hline
\end{tabular}

$\begin{array}{rrr}20 & 161 & 1.5 \% \\ 3 & 36 & 0.3 \% \\ 7 & 116 & 1.1 \% \\ 12 & 158 & 1.1 \% \\ 50 & 81 & 1.2 \% \\ 3 & 8 & 0.2 \% \\ 12 & 274 & 0.3 \% \\ 1 & 96 & 0.2 \% \\ & 930 & 6.0 \%\end{array}$

Heterogeneity: $\operatorname{Tau}^{2}=0.36 ; \mathrm{Chi}^{2}=11.82, \mathrm{df}=7(\mathrm{P}=0.11) ; \mathrm{I}^{2}=41 \%$

Test for overall effect: $Z=0.03(P=0.98)$

1.5.9 Nausea/vomiting

$\begin{array}{lrrrrr}\text { Chen T } & 8 & 113 & 16 & 161 & 1.4 \% \\ \text { Chen T Dai Z } & 0 & 19 & 1 & 36 & 0.2 \% \\ \text { Javanian M } & 11 & 19 & 34 & 81 & 1.2 \% \\ \text { Peng S } & 3 & 3 & 3 & 8 & 0.2 \% \\ \text { Wang L } & 1 & 65 & 12 & 274 & 0.5 \% \\ \text { Zhou F } & 3 & 54 & 4 & 137 & 0.8 \% \\ \text { Subtotal (95\% Cl) } & & 273 & & 697 & 4.3 \% \\ \text { Total events } & 26 & & 70 & & \end{array}$

Heterogeneity: $\operatorname{Tau}^{2}=0.12 ; \mathrm{Chi}^{2}=6.03, \mathrm{df}=5(\mathrm{P}=0.30) ; \mathrm{I}^{2}=17 \%$

Test for overall effect: $Z=0.42(P=0.68)$
$1.06[0.63,1.78]$

$3.57[1.40,9.06]$

$0.66[0.24,1.85]$

$6.00[0.34,107.42]$

$1.25[0.60,2.59]$

$1.38[0.78,2.44]$

$2.06[0.49,8.74]$

$0.70[0.40,1.20]$

$0.94[0.08,11.14]$

$1.54[0.73,3.24]$

$0.68[0.14,3.31]$

$1.00[0.09,11.59]$

$14.00[0.58,338.78]$

$1.02[0.59,1.77$

$0.96[0.42,2.18]$

$1.16[0.13,10.30]$

$0.71[0.14,3.55]$

$0.99[0.74,1.33]$

$0.76[0.35,1.66]$

$0.25[0.01,5.01]$

$0.91[0.30,2.79]$

$3.80[1.19,12.18]$

$0.56[0.20,1.53]$

$11.00[0.43,284.30]$

$0.16[0.01,2.74]$

$2.55[0.10,65.97]$

$1.01[0.50,2.03]$

$0.69[0.28,1.67]$

$0.61[0.02,15.62]$

$1.90[0.69,5.23]$

$11.00[0.43,284.30]$

$0.34[0.04,2.67]$

$1.96[0.42,9.04]$

$1.15[0.59,2.26]$

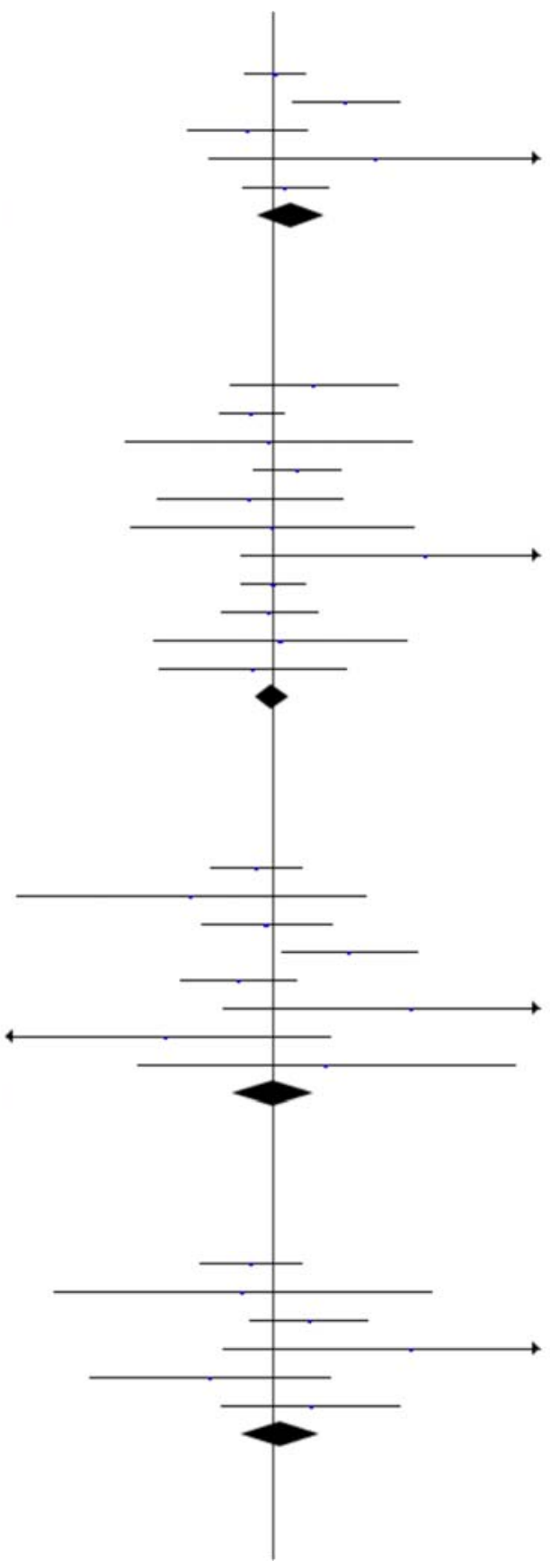


medRxiv preprint doi: https://doi.org/10.1101/2020.05.23.20110965; this version posted May 26, 2020. The copyright holder for this preprint (which was not certified by peer review) is the author/funder, who has granted medRxiv a license to display the preprint in perpetuity.

It is made available under a CC-BY-ND 4.0 International license.

\begin{tabular}{|c|c|c|c|c|c|c|}
\hline \multicolumn{7}{|c|}{ 1.5.10 Abdominal pain } \\
\hline Chen T & 6 & 113 & 13 & 161 & $1.3 \%$ & $0.64[0.24,1.73]$ \\
\hline Chen T Dai Z & 0 & 19 & 3 & 36 & $0.3 \%$ & $0.25[0.01,5.01]$ \\
\hline Javanian M & 3 & 19 & 16 & 81 & $0.9 \%$ & $0.76[0.20,2.94]$ \\
\hline $\begin{array}{l}\text { Sun } \mathrm{H} \\
\text { Subtotal }(95 \% \mathrm{Cl})\end{array}$ & 5 & $\begin{array}{l}121 \\
272\end{array}$ & 5 & $\begin{array}{l}123 \\
401\end{array}$ & $\begin{array}{l}1.0 \% \\
3.4 \%\end{array}$ & $\begin{array}{l}1.02[0.29,3.61] \\
0.72[0.37,1.40]\end{array}$ \\
\hline Total events & 14 & & 37 & & & \\
\hline \multicolumn{7}{|c|}{$\begin{array}{l}\text { Heterogeneity: } \text { Tau }^{2}=0.00 ; \mathrm{Chi}^{2}=0.84, \mathrm{df}=3(\mathrm{P}=0.84) ; \mathrm{I}^{2}=0 \% \\
\text { Test for overall effect } Z=0.96(P=0.34)\end{array}$} \\
\hline \multicolumn{7}{|c|}{ 1.5.11 Chest tightness } \\
\hline Chen T & 55 & 113 & 48 & 161 & $2.0 \%$ & $2.23[1.35,3.68]$ \\
\hline Chen T Dai Z & 17 & 19 & 18 & 36 & $0.7 \%$ & $8.50[1.71,42.2$ \\
\hline Javanian M & 12 & 19 & 31 & 81 & $1.2 \%$ & $2.76[0.98,7.78$ \\
\hline Peng S & 3 & 3 & 7 & 8 & $0.2 \%$ & $1.40[0.04,43.79$ \\
\hline Wang $\mathrm{L}$ & 15 & 65 & 73 & 274 & $1.8 \%$ & $0.83[0.44,1.5$ \\
\hline Subtotal $(95 \% \mathrm{Cl})$ & & 219 & & 560 & $5.8 \%$ & $2.04[0.99,4.2$ \\
\hline Total events & 102 & & 177 & & & \\
\hline \multicolumn{7}{|c|}{$\begin{array}{l}\text { Heterogeneity: } \text { Tau }^{2}=0.36 ; C h i^{2}=10.76, d f=4(P=0.03) ; I^{2}=63 \% \\
\text { Test for overall effect: } Z=1.94(P=0.05)\end{array}$} \\
\hline Total $(95 \% \mathrm{CI})$ & & 4315 & & 10610 & $100.0 \%$ & $1.25[1.06,1.4$ \\
\hline Total events & & & 4106 & & & \\
\hline \multicolumn{7}{|c|}{$\begin{array}{l}\text { Heterogeneity: } \mathrm{Tau}^{2}=0.28 ; \mathrm{Chi}^{2}=211.37, \mathrm{df}=95(\mathrm{P}<0.00001) ; \mathrm{I}^{2}=55 \% \\
\text { Test for overall effect: } Z=2.66(P=0.008)\end{array}$} \\
\hline st for subqroup & nces: & $=$ & & 6 & & \\
\hline
\end{tabular}

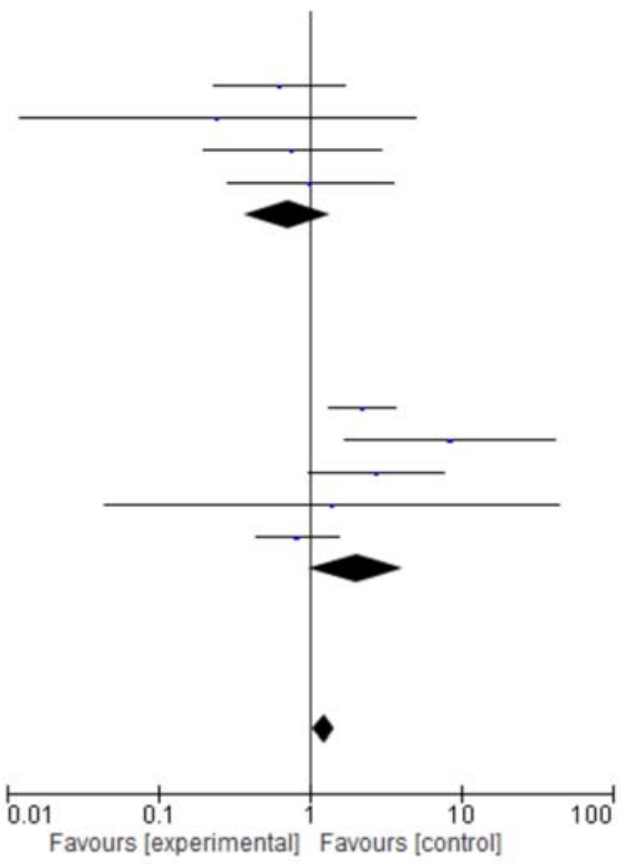

Figure 5. Pooled effects of clinical symptoms on the death linked with COVID-19 
medRxiv preprint doi: https://doi.org/10.1101/2020.05.23.20110965; this version posted May 26, 2020. The copyright holder for this preprint (which was not certified by peer review) is the author/funder, who has granted medRxiv a license to display the preprint in perpetuity.

It is made available under a CC-BY-ND 4.0 International license .

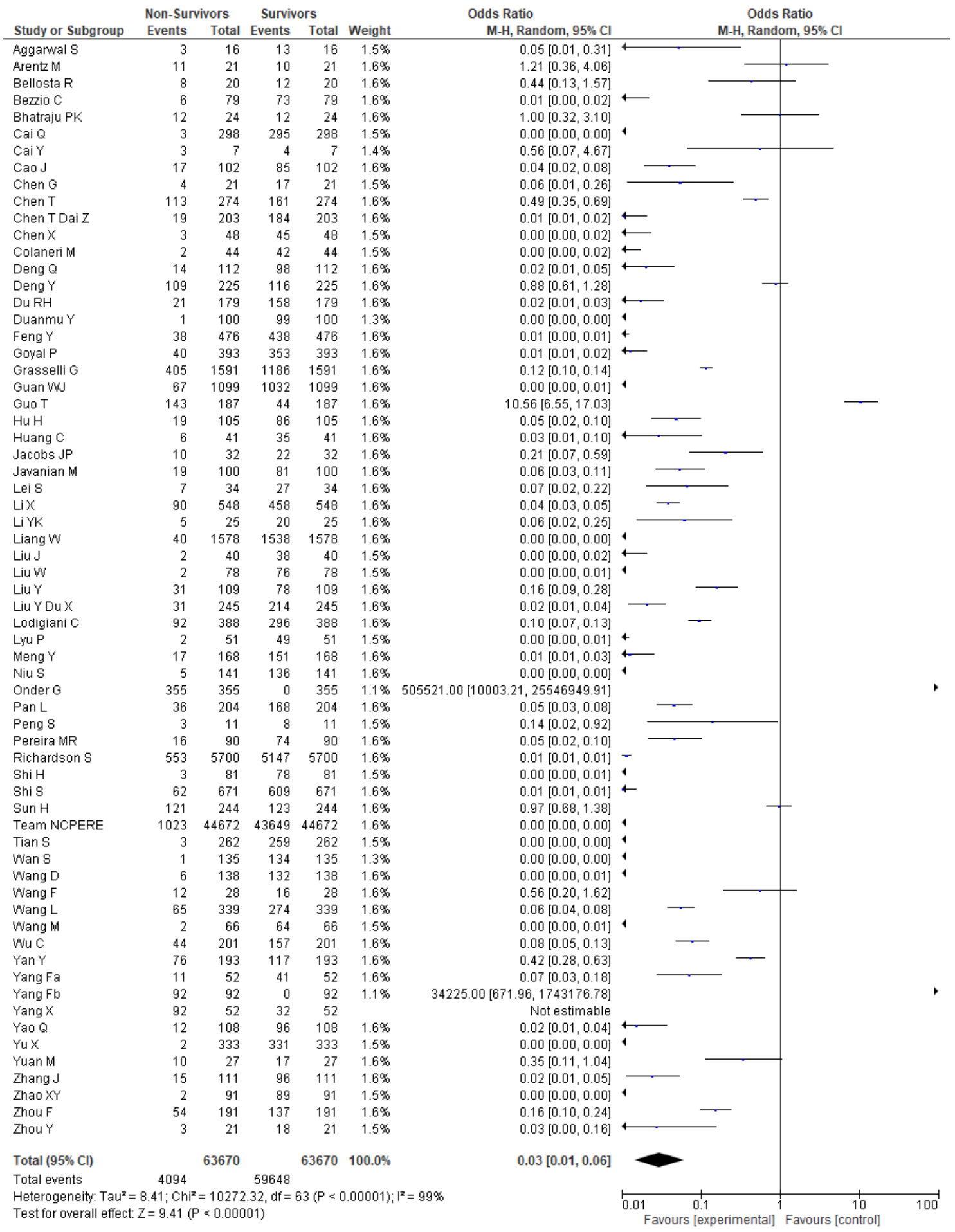

Figure 6. Mortality and survivors linked with COVID-19 
medRxiv preprint doi: https://doi.org/10.1101/2020.05.23.20110965; this version posted May 26, 2020. The copyright holder for this preprint (which was not certified by peer review) is the author/funder, who has granted medRxiv a license to display the preprint in perpetuity.

It is made available under a CC-BY-ND 4.0 International license .

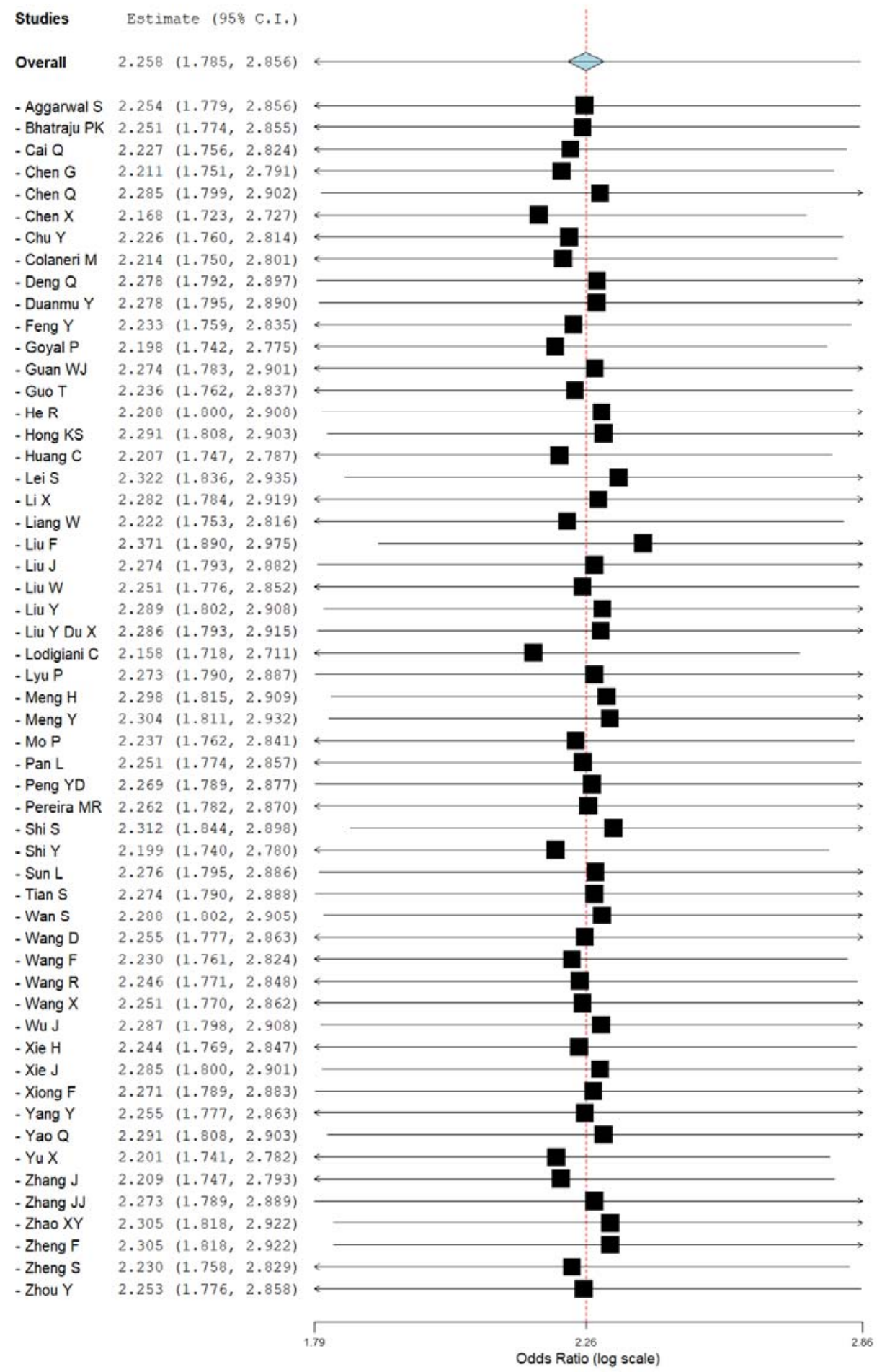

Figure 7. Sensitivity analysis of the effect of sex on the severity of COVID-19. 
medRxiv preprint doi: https://doi.org/10.1101/2020.05.23.20110965; this version posted May 26, 2020. The copyright holder for this preprint (which was not certified by peer review) is the author/funder, who has granted medRxiv a license to display the preprint in perpetuity.

It is made available under a CC-BY-ND 4.0 International license.

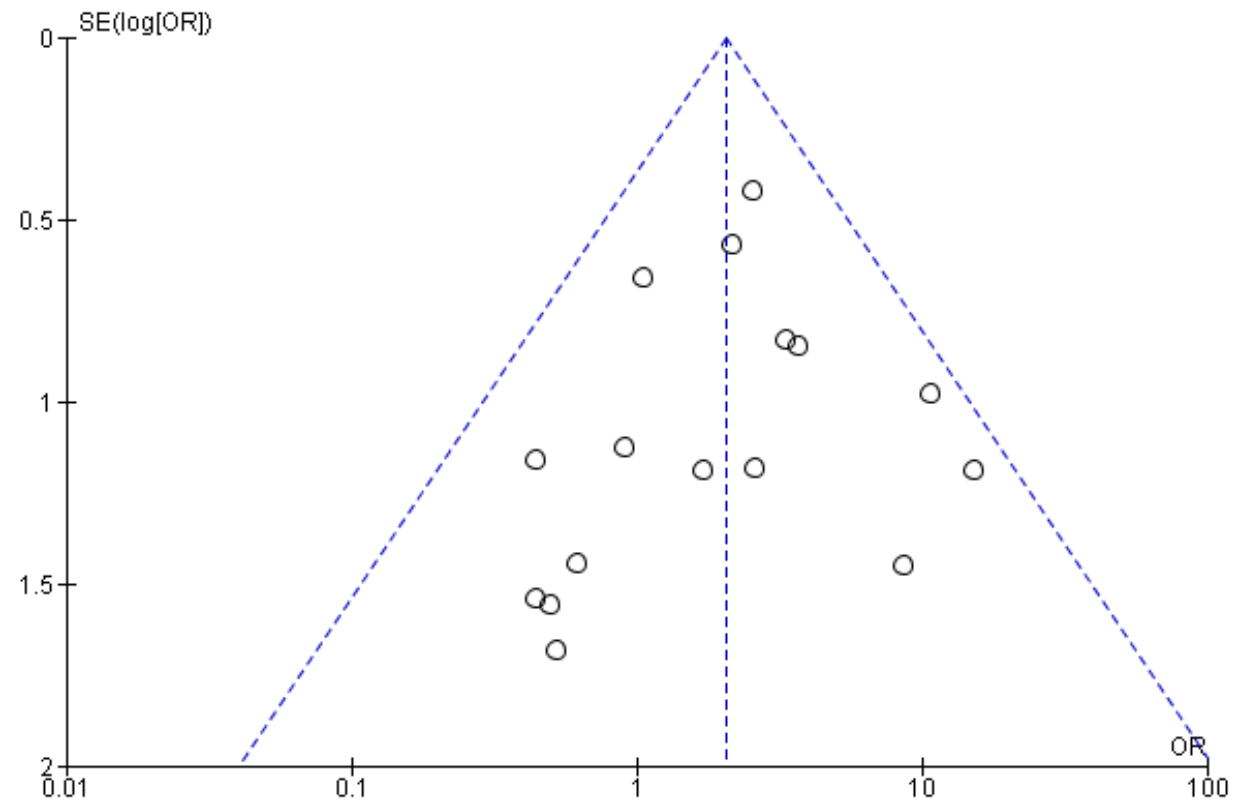

Figure 8. Funnel plot for the detection of publication bias 